\title{
The Dynamics of Protest Diffusion: Movement Organizations, Social Networks, and News Media in the I960 Sit-Ins
}

\author{
Kenneth T. Andrews \\ University of North Carolina
}

\author{
Michael Biggs \\ University of Oxford
}

The wave of sit-ins that swept through the American South in the spring of 1960 transformed the struggle for racial equality. This episode is widely cited in the literature on social movements, but the debate over its explanation remains unresolved-partly because previous research has relied on case studies of a few large cities. The authors use event-history analysis to trace the diffusion of sit-ins throughout the South and to compare cities where sit-ins occurred with the majority of cities where they did not. They assess the relative importance of three channels of diffusion: movement organizations, social networks, and news media. The authors find that movement organizations played an important role in orchestrating protest; what mattered was a cadre of activists rather than mass membership. There is little evidence that social networks acted as a channel for diffusion among cities. By contrast, news media were crucial for conveying information about protests elsewhere. In addition, the authors demonstrate that sit-ins were most likely to occur where there were many college students, where adults in the black community had greater resources and autonomy, and where political opportunities were more favorable.

$\mathrm{T}^{\mathrm{s}}$ he wave of sit-ins that swept through the American South in the spring of 1960 trans-

Please direct correspondence to Kenneth Andrews, Department of Sociology, CB \#3210, University of North Carolina, Chapel Hill, NC 27599 (kta@unc.edu) or Michael Biggs, Department of Sociology, University of Oxford, OX1 3UQ, United Kingdom (michael.biggs@sociology.ox.ac.uk). The authors are listed in alphabetical order; each contributed equally. We thank Neil Brown, Doug Grbic, Aidan Smith, and Jessica Stannard-Friehl for research assistance, and James Alt for providing an electronic copy of the Matthews and Prothro dataset for Southern counties. We also received financial support from the Center for the Study of the American South at UNC. The authors thank Takwing Chan, Larry Griffin, Peter Hedström, Charles Kurzman, Anthony Oberschall, Sidney Tarrow, the ASR editor and reviewers for their comments and suggestions. Presentations at Harvard University, New York University, University of Oxford, Russell Sage Foundation, and the American Sociological Association's annual meeting all helped to sharpen the argument. formed the struggle for racial equality. Sociological investigation began within months of the first protest (Laue [1966] 1989; Oppenheimer 1963; Searles and Williams 1962; Wehr 1960), and the sit-ins have become an exemplary case in the literature on social movements (Killian 1984; McAdam 1982, 1983; McAdam and Sewell 2001; Morris 1981, 1984; Oberschall 1973, 1989; Piven and Cloward 1977; Polletta 1998). Despite the amount of research devoted to the sit-ins, there is no consensus on why they occurred. Some sociologists (e.g., Morris 1981, 1984) argue that movement organizations, especially the Southern Christian Leadership Conference (SCLC), played the crucial role of coordinating and mobilizing protest. Others (e.g., Killian 1984; Oberschall 1989) contend that the wave was spontaneous, with college students in various cities adopting this novel form of protest because they were inspired by the actions of students elsewhere. Previous research has not compared the cities swept up in the wave with the more numerous cities that remained untouched. 
In this article, we provide a systematic and comprehensive investigation of the diffusion of sit-ins throughout the South in the spring of 1960. We assess the relative importance of three channels of diffusion-movement organizations, social networks, and news media-and identify the characteristics of a city that made protest more likely. Event-history analysis is used to predict the onset of sit-in campaigns in the ten weeks following the initial event in Greensboro, North Carolina. This day-by-day analysis encompasses 334 cities. In addition, we scrutinize qualitative evidence on the process of diffusion and analyze coverage in four Southern newspapers.

Our findings offer a new and complex explanation for the diffusion of sit-ins. Movement organizations did play a role in orchestrating the sit-ins, though the role was not as significant as some have argued. The organization with the greatest impact was actually the Congress of Racial Equality (CORE) rather than SCLC. Membership of the National Association for the Advancement of Colored People (NAACP) had no discernible effect. There is surprisingly little evidence that social networks acted as a channel for diffusion among cities. By contrast, news media were crucial. Protesters recalled first learning about sit-ins in other cities from newspaper, radio, or television. Event-history analysis demonstrates that protest tended to follow the newspaper circulation network. In addition, the impact of sit-ins in other cities diminished with distance just as the likelihood of news coverage diminished with distance.

Along with these findings on diffusion, we confirm that college students led the protest, and that protest was more likely to occur in cities where adults in the black community had greater resources and autonomy and where political opportunities were more favorable.

These findings have important lessons for the literature on social movements. Attention has recently focused on the factors determining which protest events are reported by the media (e.g., Maney and Oliver 2001; Myers and Caniglia 2004; Smith et al. 2001). Few studies, however, examine whether reports of protest can inspire further acts of protest elsewhere. By combining quantitative analysis of protest events and of newspaper coverage, we demonstrate how the media can inadvertently propa- gate a protest wave (see also Koopmans and Olzak 2004).

We begin by sketching the course of events and reviewing scholarship on the sit-ins. From these studies and the wider literature on social movements and collective action, we develop hypotheses to explain the diffusion of protest. We outline the method and data for the eventhistory analysis and then present the results. To complement the results, we analyze the pattern of newspaper coverage and scrutinize qualitative evidence on the process of diffusion. The conclusion draws implications for future research.

\section{THE SIT-INS OF I960}

With hindsight, we tend to perceive a civil rights movement emerging after World War II and building inexorably to a crescendo in the mid1960s. This conventional narrative conceals discontinuities and critical moments of rapid mobilization (Carson 1986; McAdam and Sewell 2001). In fact, activists faced a bleak situation at the end of the 1950s. The NA.ACP had won a landmark legal ruling in Brown, but the main effect was to provoke massive resistance by white Southerners to school desegregation (Klarman 1994). The organization itself was outlawed in Alabama. The achievements of SCLC - which had emerged from the victorious bus boycott in Montgomery, Alabama-were also disappointing. Its major campaign for voter registration, the "Crusade for Citizenship," floundered. In 1958 Ella Baker, overseeing the campaign, feared that "we are losing the initiative in the civil rights struggle" (Fairclough 2001:240). This changed dramatically in the spring of 1960 .

On February 1, four freshmen from North Carolina Agricultural and Technical (A\&T) College in Greensboro occupied the lunch counter of Woolworth's after being refused service. The protest was repeated, with increasing numbers of students, on the following days (Chafe 1980; Wolff 1970). This form of protest, soon known as a "sit-in," was not new. It can be traced back to 1943, when a handful of CORE activists occupied a Chicago restaurant that refused service to blacks (Meier and Rudwick 1973). In the 1950s there were several sit-ins in the South, though these were tentative tests rather than concerted campaigns, and they did 
not spread to other cities (Morris 1984). A wave of sit-ins in 1958 began in Wichita, Kansas, and spread south to Oklahoma City and three other cities in Oklahoma (Eick 2002; Graves 1981; Luper 1979). These sit-ins were initiated by local NAACP Youth Councils and were conducted primarily by students from high school. Protest was sustained over many months, and it eventually succeeded in forcing several downtown lunch counters to serve blacks. Although NAACP's national leadership had initially opposed the sit-ins, the organization subsequently highlighted these victories at its annual convention and in its magazine in 1959 . However, there is surprisingly little evidence linking these previous events with Greensboro. The four freshmen who started the protest disclaimed any knowledge of what had happened in Oklahoma (Warren 1965:360).

By contrast, the sit-ins in Greensboro inspired blacks in other cities to adopt this form of protest. After a week, sit-ins began elsewhere in North Carolina; soon the wave of protest surged into other states. Figure 1 traces the course of this wave in the South (including Maryland, Kentucky, and West Virginia along with the states of the former Confederacy). Within two months of the initial event in Greensboro, sitins had been staged in every Southern state except Mississippi. In each city, protest typically began with students occupying seats at downtown lunch counters of "five and dime" stores, disrupting business; this often led to confrontation with the police or hostile whites. Sitins were accompanied by established forms of protest such as picketing, boycotts, and demonstrations. Although these campaigns extended over many months, the spread of sit-ins to new cities declined by the end of the spring, leaving most cities untouched.

The consequences of this protest wave can hardly be overstated. The sit-ins mobilized tens of thousands of blacks (and hundreds of whites) and created a new movement organization, the Student Nonviolent Coordinating Committee (SNCC). In many cities, the sit-ins forced white leaders to negotiate, and eventually broke the taboo against interracial dining. Nashville was the first major city to succumb, in May 1960. While civil rights advocates had been relying primarily on litigation and organization building, such tangible victories elevated protest as the central strategy of the movement in the years to follow. The impact of the sit-ins was not only confined to African Americans; SNCC also proved influential for the white New Left and other social movements (Carson 1981). As

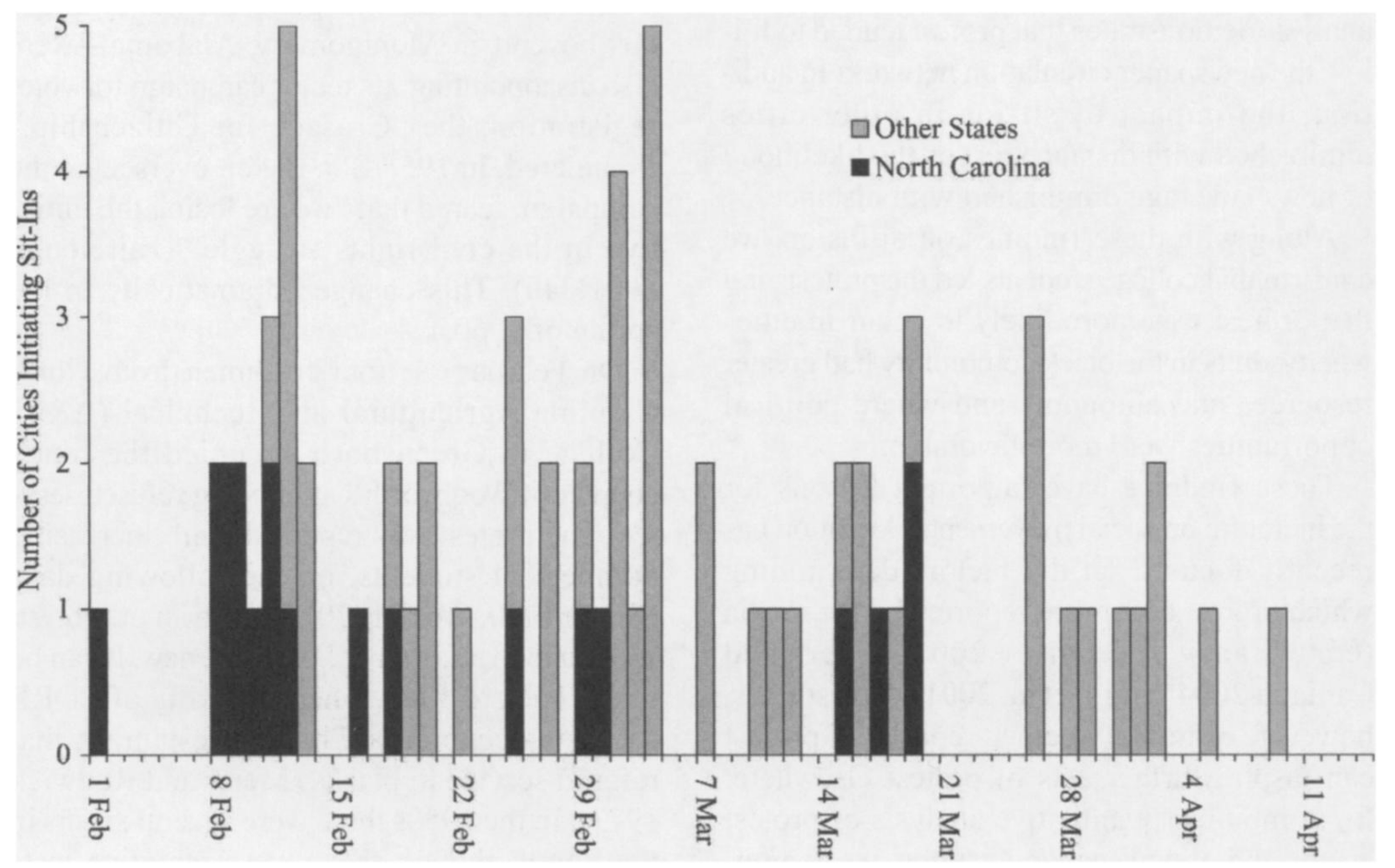

Figure 1. Sit-Ins in the American South, February 1 to April 14, 1960 
Morris puts it, the sit-ins were the "origins of a decade of disruption" (1984:195).

How to explain these events-especially how to explain the rapid diffusion of protest - has been vigorously debated by scholars of social movements. The debate has been framed as one of spontaneity versus organization. College students themselves used a narrative of spontaneity, which signified "independence from adult leadership, urgency, local initiative, and action by moral imperative" (Polletta 1998:138). This narrative, shared by contemporary observers (e.g., Constable 1960; Lomax 1960, 1962), was developed in subsequent sociological analyses (e.g., Piven and Cloward 1977). Morris (1981, 1984) challenged the notion that the sit-ins developed spontaneously, arguing instead that they "grew out of pre-existing institutions and organizational forms" (1981:744). The most important of these institutions was the network of activist churches linked together by SCLC; "sit-ins were largely organized at the movement churches, rather than on the campuses" (Morris 1981:757). Morris' account was in turn challenged by Killian (1984) and Oberschall (1989), who argued that it overestimated the role of established leaders and underestimated conflict between them and student activists. This debate is not only about what happened in 1960; it also has crucial theoretical implications. Spontaneity fits the older theory of collective behavior and is also compatible with rational choice theory (Oberschall 1989). By contrast, an emphasis on preexisting organization dovetails with solidarity/mobilization theories, which continue to dominate scholarship on social movements (see also McAdam 1982).

The debate over how to explain the sit-ins has yet to be resolved. Moreover, previous research has been limited by substantial methodological problems. The first problem is selection on the dependent variable. Research has focused entirely on cities with sit-ins - and predominantly on a few large cities like Nashville and Tallahassee. By contrast, the majority of cities where no protest occurred are ignored. ${ }^{1}$ No comparison

\footnotetext{
${ }^{1}$ Exceptionally, Oppenheimer (1963) discussed Lawrenceville, Virginia, where black studentse decided not to sit in; he explained this as due to the town's small size, isolation, economically vulnerable black population, and lack of organizations.
}

has been undertaken to identify what differentiated cities with sit-ins from those without. ${ }^{2}$ The second problem is the contradictory biases of qualitative evidence-contemporary testimony and retrospective interviews - on the role of movement organizations. On one hand, black protesters faced powerful incentives to emphasize local initiative to avoid charges of being led astray by "outside agitators" (Killian 1984:783). In Charlotte, North Carolina, for example, local leaders disavowed any contact with groups like CORE (Oppenheimer 1963:177, 180; Polletta 1998). On the other hand, when it became apparent that the sit-ins had reinvigorated the movement against racial oppression, leaders had powerful incentives to magnify their own role in organizing protest. These biases exacerbate the difficulties of interpreting qualitative evidence (see also Carson 1986).

Previous research has considered diffusion, showing that sit-ins tended to occur earlier in places closer to Greensboro (Laue [1966] 1989; McAdam 1982; Morris 1981; Oppenheimer 1963; Orum 1972). This research, however, overlooks the majority of cities that remained untouched by sit-ins. It also fails to separate geographical distance from social differences; for example, the Upper South was much less repressive than the Deep South. We overcome these problems by using an event-history model of diffusion (Strang and Tuma 1993). This method has been used to analyze strikes, riots, and campus protest (Conell and Cohn 1995; Myers 1997, 2000; Olzak, Beasley, and Olivier 2003; Soule $1997,1999)$ as well as organizational founding (Conell and Voss 1990; Hedström 1994; Hedström, Sandell, and Stern 2000) and repressive violence (Beck and Tolnay 1990; Tolnay, Beck, and Deane 1996). Event-history analysis allows us to analyze simultaneously where sitins occurred, when they occurred, and how they spread from one city to another. This analysis can be buttressed by scrutinizing qualitative evidence on the process of diffusion. By combining these methods, we hope to explain why

\footnotetext{
${ }^{2}$ A survey of black students in 1962 (Matthews and Prothro 1975) enables systematic comparison between those who participated in sit-ins and those who did not (Biggs forthcoming), but does not reveal the dynamics of diffusion.
} 
sit-ins multiplied so rapidly across the South after February 1.

\section{THEORY AND HYPOTHESES}

For potential explanations, we draw widely from the literature on collective protest. The wave of sit-ins in the spring of 1960 resembled other episodes where confrontational protest has spread rapidly. Participants and observers used metaphors such as "fever," "contagion," and "grass fire," just as they have in other protest waves (Oppenheimer 1963; Polletta 1998; Southern Regional Council 1960; Walzer 1960). There was clearly a process of positive feedback (Biggs 2003, 2005): blacks in one city initiated sit-ins because others elsewhere, beginning with Greensboro, had done so. For the vast majority of protesters, the sit-in was a novel form of protest (and eating places that denied service to blacks were a novel target); it was not part of the existing repertoire of contention (Tilly 1977, 1995; Traugott 1993). In the initial months there was no proof that the sit-ins would ultimately achieve success. But as the sit-ins spread, the fact that so many protesters were hopeful of success inspired blacks in other cities to initiate sit-ins. "For the Negroes, this rapid growth did a great deal to enhance its hope of victory," recalled William Peace (1962:101), a student at Raleigh's Shaw University.

In outline, this abstract characterization of the process should not be controversial. The question is how exactly it occurred. What were the most important "channels" of diffusion: movement organizations, social networks, or news media? The term "channel" is most appropriate for the media, which could provide a conduit for information about protest events elsewhere. Organizations, by contrast, could actively coordinate protest and exhort their members to take part. With this qualification, we believe that the trichotomy covers the major potential explanations for diffusion. Networks and organizations are often treated together under the heading of "relational" diffusion (see McAdam and Rucht 1993), but it is worth distinguishing between the social networks of ordinary life (relatives, friends, coworkers) and the networks created intentionally by movement activists to further their goals. The trichotomy of organizations, networks, and media provides our first three explanatory hypotheses.
The central point of contention in the literature is the role of movement organizations. Consistent with resource mobilization and political process theories, Morris (1981) and McAdam (1982) argue that organization was a precondition of protest. The presence of a movement organization in a city provided a cadre of activists who could orchestrate protest. Local activists could be directly inspired by protest occurring elsewhere. Alternatively, an organization's leaders could coordinate or encourage local activists to act. In 1960, NAACP was by far the strongest movement organization, with branch membership comprising an impressive 1.5 percent of the urban black population in the South. NAACP also organized separate College Chapters and Youth Councils. SCLC, by contrast, did not recruit individual members; it was really a "meso-level network" (Hedström et al. 2000) of activist ministers. CORE had few Chapters in the South, but it had the greatest experience with the sit-in tactic (CORE 1960). This diversity of organizations means that we can ask not only whether movement organizations orchestrated protest but also which type of organization was most significant. Some scholars argue that bureaucratic membership organizations like NAACP, despite-or because of - their apparent power, are reluctant to sanction disruptive protest (Piven and Cloward 1977). Morris $(1981,1984)$ argues that SCLC, along with NAACP Youth Councils, played the most important role in orchestrating sit-ins.

Hypothesis 1: Protest was orchestrated by movement organizations.

Social networks provide another channel of diffusion. As protest occurred in one locality, people there could inform and encourage their acquaintances elsewhere, who in turn could be inspired to initiate protest. This channel was suggested by Baker: "A sister who had a brother in school in another town, her town had already sat in. She might call and ask, why doesn't his school sit in?" (Cantarow 1980:83). McAdam even postulates a "well-developed communication network linking the southern black college campuses into a loosely integrated institutional network" (1982:138; see also Tarrow and McAdam 2005). One particular network has been identified as significant, the intercollegiate athletic circuit. Walzer (1960) suggested that sit-ins were propagated by A\&T's 
basketball team as it played other colleges in North Carolina in the first two weeks of February (see also Oberschall 1989). In fact, the team's games preceded sit-ins only in Durham, and Oppenheimer's (1963) subsequent interviews with protesters found no evidence to support this notion. Nevertheless, intercollegiate athletics is worth considering as a proxy for social networks linking students in different cities. These affiliations were imbued with rivalry, which helped motivate protest. A sociology professor in Tallahassee observed that "an element of competition between Negro colleges has become a part of the civil rights struggle ... and no college or university wants to be left behind" (Smith 1961:228; see also Laue 1966:82; Wehr 1960:25).

Hypothesis 2: Protest was inspired by information about protest occurring elsewhere, conveyed by social networks.

The media provide an alternative channel of diffusion. As protest was reported in the news, this could inspire others elsewhere to initiate protest. A few recent studies demonstrate that the news media can have a significant effect in propagating protest (Koopmans and Olzak 2004; Myers 2000). ${ }^{3}$ For the sit-ins, contemporary accounts emphasize the media (Laue 1966; Oppenheimer 1963:61-62; Wehr 1960). From a representative survey of black college students in the South in 1962 (Matthews and Prothro 1975), we know that almost all (93 percent) read a newspaper more or less regularly, while a large majority ( 83 percent) listened to radio and two-thirds watched television more or less regularly (see also Ward 2004). ${ }^{4}$

Hypothesis 3: Protest was inspired by information about protest occurring elsewhere, conveyed by news reports.

These three hypotheses reframe the debate over organization versus spontaneity in a way that

\footnotetext{
${ }^{3}$ Roscigno and Danaher (2000) argue that radio stations influenced textile strikes during the Great Depression, because they supported itinerant musicians and broadcast messages from the president; news reports, however, are not part of their argument.

${ }^{4}$ These figures are restricted to students attending colleges located in cities in our dataset $(n=218)$.
}

incorporates insights from recent scholarship on the diffusion of protest. Advocates of organization would clearly expect strong empirical support for Hypothesis 1; those who characterize the sit-ins as spontaneous would expect that hypothesis to be rejected, and presumably would expect empirical support for Hypotheses 2 and 3 . We will evaluate these hypotheses using event-history analysis. Hypothesis 1 is readily tested by measuring the presence or membership of movement organizations in each city. Hypothesis 2 implies that the impact of sit-ins in other cities will diminish with distance, as personal acquaintances are more likely to live nearby. Hypothesis 3 has the same implication so long as potential protesters depend on news media located in their own or nearby cities, which are most likely to report events occurring close to home. This indeed was borne out by the survey of black students: newspaper readers were most likely to read a newspaper published in their own city, and then a newspaper published somewhere else in the South (Matthews and Prothro 1975).

Because Hypothesis 2 (social networks) and Hypothesis 3 (news media) both imply that the impact of sit-ins will diminish with distance, ingenuity is required to distinguish between them. As a particular test of Hypothesis 2, we will use intercollegiate athletic associations as a proxy for social networks. There were seven associations; affiliation depended on region and college status. Colleges in the same association fielded teams that regularly traveled to each other's campus and that were also connected by collegial rivalry. We can test whether the diffusion of sit-ins tended to follow these intercollegiate links. As a particular test of Hypothesis 3, we will use newspaper circulation. News media are especially likely to report events in their home city; these reports are then circulated or broadcast to a wider area. This creates what Myers (2000) calls an "asymmetric network," because news tends to flow from larger cities where news organizations are headquartered to more peripheral or smaller cities. ${ }^{5} \mathrm{We}$ can test whether the diffusion of sit-ins tended

\footnotetext{
${ }^{5}$ Myers (2000) also suggests another specification, the "responsive network." We have tested this specification, and find that it has no effect.
} 
to follow the flow of news, by reconstructing the network of newspaper circulation among cities.

Alongside these explanations for the diffusion of protest, we can examine potential explanations for why protest was more likely in some cities than others. Three further hypotheses can be tested. One hypothesis concerns the role of students. The conventional view is that the sitins were largely the work of college students. This accords with the argument that dense social networks within a college campus facilitate mobilization, especially where students live in dormitories (McAdam 1982; Orum 1972; Van Dyke 1998; Zhao 1998). In addition, students are rather less constrained by the demands of employment and childcare than adults. "As college students," remarked one of the Greensboro four, "we have no jobs from which to be fired by people who don't like to see us assert ourselves" (Dykeman and Stokely 1960:12). Nevertheless, Morris argues that the role of students has been exaggerated: "to understand the sit-in movement, one must abandon the assumption that it was a collegiate phenomenon" (1981:757). We can test this disagreement.

Hypothesis 4: Protest was more likely where there were many college students.

Even if college students led the sit-ins, adults in the black community may have been important too. Students could have been more likely to protest where they anticipated that support (such as money for bail or attorney's fees in case of arrest) would be forthcoming from adults. McAdam (1982) points out that cities were less oppressive than rural plantations. By the same logic, we expect that urban communities varied in the extent to which adults had sufficient resources and autonomy to support or participate in protest. Specifically, blacks in unskilled occupations may have been least able to challenge racial oppression (James 1988; Salamon and Van Evera 1973). The underlying theoretical rationale is really the same as for the previous hypothesis: a maid toiling for a white family is at the other end of the spectrum from a student at an elite university.

Hypothesis 5: Protest was more likely where the adult community had greater autonomy and resources.

Political opportunities refer to the configuration of institutions, allies, and opponents that enable or constrain protest (McAdam 1995; Meyer and
Minkoff 2004). The civil rights movement has been the core case around which these ideas have been developed (Andrews 2004; Jenkins, Jacobs, and Agnone 2003; McAdam 1982, 1983; Meyer and Minkoff 2004). This line of thinking was initially formulated to explain cross-sectional variation across localities (Eisinger 1973), and political opportunities have been used to explain variation among municipalities, counties, states, and countries (Amenta, Dunleavy, and Bernstein 1994; James 1988; Kriesi et al. 1995). The sit-ins were initiated first in the least repressive areas of the South, as many have observed (e.g., Constable 1960; Pollitt 1960).

Hypothesis 6: Protest was most likely to occur where political opportunities were more favorable.

\section{RESEARCH DESIGN}

\section{DEPENDENT VARIABLE AND MODEL}

Our analysis investigates cities (rather than counties), because sit-ins targeted the downtown shopping district. We include 334 urban places with a total population of at least ten thousand and a black population of at least one thousand. ${ }^{6}$ Only a handful of smaller places experienced sit-ins. Our analysis begins on February 1, when the first sit-in occurred in Greensboro. It ends on April 14, the day before student activists held a conference at Shaw University which eventually led to the creation of SNCC. By terminating analysis at this point, we exclude consideration of the outcome of the sit-in campaigns. By mid-April, it was still an open question whether the sit-ins would achieve their aims of breaking down racial barriers. ${ }^{7}$ The analytic advantage is that we can be sure that protest was inspired by expectations of success rather than actual success.

\footnotetext{
${ }^{6}$ The census provides detailed information on the "nonwhite" population; in these states, blacks made up the vast majority of nonwhites.

${ }^{7}$ The only exception was Galveston, Texas, where sit-ins forced merchants to serve blacks in early April. In North Carolina, some dining establishments removed their stools, forcing everyone to dine while standing, but this was a temporary expedient.
} 


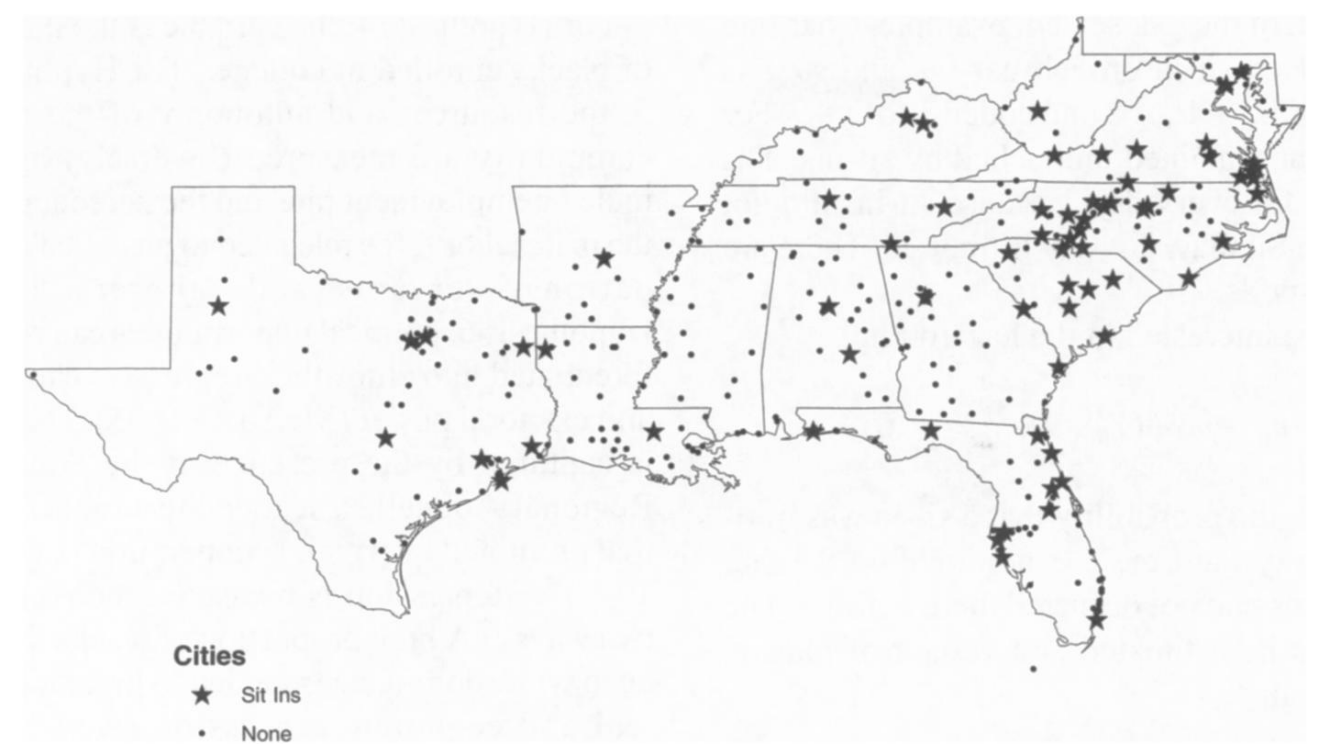

Figure 2. Map Showing Sit-Ins in the American South, February 1 to April 14, 1960

The dependent variable is derived from the date of a city's first sit-in. We define this as a physical occupation of space from which blacks were excluded, usually a commercial eating establishment but occasionally a public facility such as a library. We exclude demonstrations that did not physically occupy segregated spaces as well as cases where the mere threat of protest sufficed to bring about negotiations. Dates of the first sit-in come from contemporary listings (Laue [1966] 1989:Appendix F; Oppenheimer 1963:63-64; Southern Regional Council 1960:xix-xxv). Because they were compiled from multiple newspaper reports, these are far more comprehensive in coverage than the $\mathrm{New}$ York Times or any single newspaper. ${ }^{8}$ In a few cases, discrepancies between these sources have been resolved by information from NAACP and CORE papers and from local newspapers. Sit-ins occurred in 66 cities; four out of five cities remained unaffected. As Figure 1 depicted the diffusion of sit-ins through time, Figure 2 reveals their diffusion over space.

The first sit-in in a city usually marked the beginning of a prolonged campaign, often involving picketing and boycotts as well as fur-

\footnotetext{
${ }^{8}$ Of the four major Southern newspapers we have examined, the Charlotte News was the most comprehensive, but it reported only 73 percent of the sit-in campaigns that we identify.
}

ther sit-ins. Take the example of Charlotte: the first sit-in occurred on February 9, and sit-ins continued until the 12th when they were halted at the mayor's request; protest was repeated from the 15th to the 18th and again on the 27th; sit-ins and picketing continued sporadically through March and April (Oppenheimer 1963). Our analysis excludes such subsequent events from consideration for pragmatic and theoretical reasons. It would be impractical to gather evidence on the daily occurrence of sit-ins after the first event. Moreover, we expect that the initial sit-in-which demonstrated that some of the city's blacks were willing to physically violate racial segregation - was the most important signal for blacks elsewhere. This expectation can be tested (and will be confirmed) by estimating how the impact of the initial sit-in diminished with time.

We seek to explain why blacks initiated sitins in some cities but not others - and why they protested sooner in some places than others. This requires event-history analysis. A discretetime model is appropriate because many events are tied with others (on many days, sit-ins were initiated in multiple cities). The unit of analysis is the "spell," or city-day. The dependent variable is $Y_{i t}$ a dichotomous variable coded 1 if a sit-in occurred in city $i$ at time $t$, and 0 otherwise. The index $t$ begins at 1 (February 1) and ends at 74 (April 14). Each city enters the dataset on every day that it was "at risk" of an initial sit-in. Once a sit-in occurred, the city 
drops out of the risk set. For example, Charlotte had its first sit-in on February 9, and so $Y$ is coded 0 for $t=1 \ldots 8$ and coded 1 for $t=9$. For cities that remained untouched by sit-ins, $Y$ is coded 0 for every day. Because sit-ins did not occur on Sunday, this day is omitted. There are 18,990 spells.

We are interested in the hazard rate:

$$
p_{i t}=\operatorname{prob}\left(Y_{i t}=1 \mid \sum_{\tau=1}^{t-1} Y_{i \tau}=0\right)
$$

This is the probability that a sit-in was initiated in city $i$ at time $t$, conditional on the fact that sit-ins had not occurred there before $t$. The model to be estimated is a variant of logistic regression:

$$
\ln \left(\frac{p_{i t}}{1-\mathrm{p}_{i t}}\right)=\alpha_{0}+\alpha_{1} W_{t}+\Sigma \beta_{k} X_{k i}+\Sigma \delta_{m} D_{m i t}
$$

where $\alpha, \beta$, and $\delta$ are coefficients to be estimated. The characteristics of each city are measured by $k$ cross-sectional (time-invariant) variables, $X_{k}$ Over such a short period, there is no reason to estimate a separate intercept for each time $t$. It is necessary only to represent the weekly rhythm of events. Sit-ins were more frequent on Thursday, Friday, and Saturday, which together are indicated by the dichotomous variable $W_{t}$. The impact of sit-ins elsewhere is captured by $m$ diffusion variables, $D_{m}$.

\section{EXPLANATORY VARIABLES}

Table 1 lists descriptive statistics and bivariate correlations for the explanatory variables (see Appendix for sources and definitions). We begin by describing hypotheses that can be tested by cross-sectional variables. For Hypothesis 1 , five variables measure the extent of movement organization. NAACP had branches in 206 cities. Its strength is measured by the number of branch members. In addition, dichotomous variables are coded for the presence of a separate Youth Council (in 125 cities) or College Chapter (in only 15). Neither SCLC nor CORE had a formal structure of local branches. We define a dichotomous variable for SCLC by coding the presence of an affiliated organization or member of the executive board (located in 34 cities), and for CORE by coding the presence of a Chapter that had applied to affiliate with the national organization (located in 12 cities).
For Hypothesis 4, the variable is the number of blacks enrolled in college. ${ }^{9}$ For Hypothesis 5 , the resources and autonomy of the black community are measured (inversely) by the male unemployment rate and the percentage of the male labor force relegated to unskilled occupations-servants and laborers. ${ }^{10}$ For Hypothesis 6, political opportunities can be differentiated into elite allies, repressive capacity, and electoral power (McAdam 1995). The first is captured by the presence of the Southern Regional Council, a leadership organization that promoted interracial cooperation (Egerton 1995). ${ }^{11}$ Repression is measured indirectly in two ways. ${ }^{12} \mathrm{~A}$ high proportion of blacks threatened white dominance, and led to greater political and economic repression (Key 1949; Matthews and Prothro 1963). Therefore the percentage of blacks in the county is an important variable; we allow for a non-monotonic effect by introducing a squared term (an orthogonal polynomial which eliminates the problem of collinearity). ${ }^{13}$ There is also a dichotomous variable for states of the Deep South, where repression was more extreme. Electoral power is measured (inversely) by the existence of a state poll tax, which was designed to disenfranchise blacks. $^{14}$

\footnotetext{
${ }^{9}$ Separate variables for elite and non-elite institutions (based on the faculty-student ratio) did not reveal significant effects.

${ }^{10}$ Variables for median years of schooling, median male individual income, and the percentage of the male labor force in professional and technical positions did not reveal significant effects.

${ }^{11}$ Variables for white college students and establishments owned by Fortune 1000 corporations in the county (following James 1988) did not reveal significant effects.

12 Matthews and Prothro's (1966:166-7) measure of violence against blacks between 1955 and 1959 did not reveal a significant effect. We have not included a measure of repressive action such as arrests or violence during the sit-in campaigns because of the obstacles to collecting valid data across all cities throughout this period. Qualitative evidence, however, suggests that repression had minimal effect on the spread of protest. Most arrests occurred in a few cities and toward the end of the protest wave (Oppenheimer 1963).

${ }^{13}$ An orthogonal squared term is the residual from regressing $X^{2}$ on $X$.

${ }^{14} \mathrm{~A}$ variable for the percentage of blacks registered to vote (U.S. Commission on Civil Rights 1959) did not reveal a significant effect.
} 


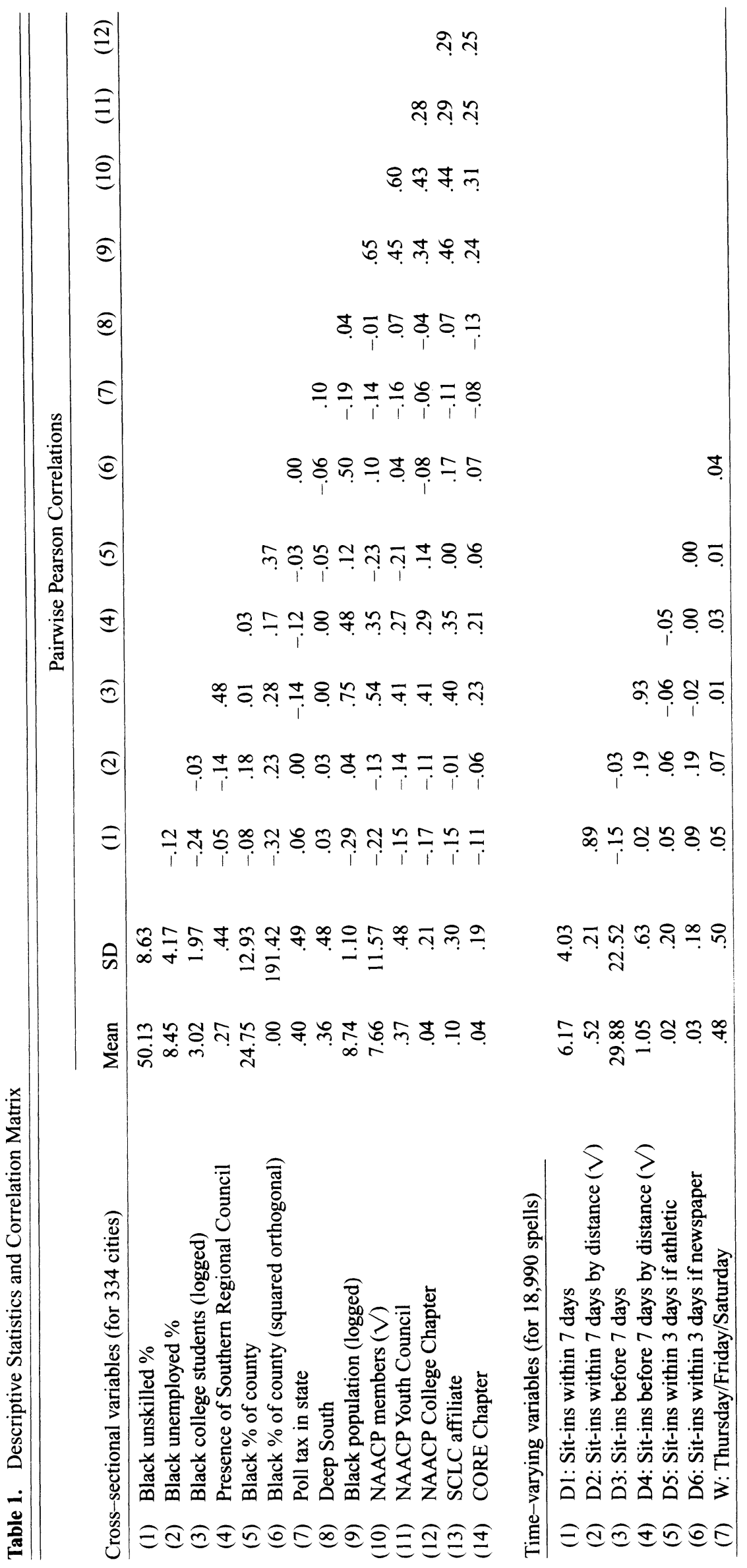


The black population is entered as a control variable. ${ }^{15}$ For variables that count the number of people, a diminishing marginal effect would be expected. To take an example, the difference between 100 and 200 college students should be much greater than the difference between 1000 and 1100 . Therefore these variables are logged - excepting NAACP membership, where the square root is taken. ${ }^{16}$

Diffusion variables capture the impact of previous sit-ins elsewhere. Formal notation helps to clarify their construction. They are derived from a dichotomous variable $S_{j \tau}$, coded 1 if sitins were initiated in city $j$ in time $\tau$, and 0 otherwise. ${ }^{17}$ The initiation of sit-ins in another city would have the greatest impact in the following days, as it provided new information about the willingness of blacks elsewhere to defy segregation. We have adopted (after testing alternatives) a duration of seven days - just like the 1960s riots (Myers 1997:97-98, 2000:185). To facilitate interpretation, there is no time decay within those seven days. The first diffusion variable simply counts the number of cities:

$$
D_{1 i t}=\sum_{\tau=t-7}^{t-1} \sum_{j=1}^{J} S_{j \tau}
$$

Hypotheses 2 and 3 imply that the impact of prior events elsewhere will diminish with the distance between the cities, $d_{i j}{ }^{18}$ The functional form adopted, after testing alternatives, is

${ }^{15}$ The black population is more appropriate than the total population, as few whites participated in the sit-ins. The two figures are highly correlated $(r=.91)$, and so substituting the total population makes no difference to the results.

${ }^{16}$ Where the number of black college students is zero, it is transformed as $\ln (1)=0$. This procedure is inappropriate for NAACP membership, because a few cities had only a single member.

${ }^{17} S$ is identical to $Y$, but a distinct symbol helps to clarify the difference between the dependent variable (what happens here today) and the diffusion variables (what happened in other cities before today).

${ }^{18} \mathrm{~A}$ few of the cities are very close to one another, as close as one mile. There is only a single instance of sit-ins in one city being followed by sit-ins in another city less than 10 miles away, and that happened over a week later. Because the inverse square root would give excessive weight to very close events, distances less than 10 miles are treated as 10 miles. the inverse square root (cf., Hedström et al. 2000). ${ }^{19}$ The resulting sum is highly skewed, and so the square root is taken. The formula is thus the following:

$$
D_{2 i t}=\sqrt{\sum_{\tau=t-7}^{t-1} \sum_{j=1}^{J} \frac{S_{j \tau}}{\sqrt{d_{i j}}}}
$$

Together, $D_{1}$ and $D_{2}$ capture the influence of sitins within seven days.

The initiation of sit-ins could also have a more enduring impact, especially because the initial event usually inaugurated a continuing campaign of protest. A pair of diffusion variables, $D_{3}$ and $D_{4}$, captures the influence of earlier events:

$$
\begin{gathered}
D_{3 i t}=\sum_{\tau=1}^{t-8} \sum_{j=1}^{J} S_{j \tau} \\
D_{4 i t}=\sqrt{\sum_{\tau=1}^{t-8} \sum_{j=1}^{J} \frac{S_{j \tau}}{\sqrt{d_{i j}}}}
\end{gathered}
$$

Two more elaborate diffusion variables require reconstructing how some cities were connected to others. Hypothesis 2 is tested using networks among black colleges established by affiliation with the same athletic association. The Central Intercollegiate Athletic Association, for example, linked various colleges in Maryland, Virginia, and North Carolinaincluding Charlotte's Johnson C. Smith University. A sit-in in Charlotte, we hypothesize, should have a particularly great impact on an affiliated city, because students there would be more likely to know someone at Johnson C. Smith University, and moreover because they would not want to be outdone by the rival campus. A matrix is created with elements $a_{i j}$ coded 1 if there was a college in city $j$ that was affiliated with the same athletic association as a college in city $i$, and 0 otherwise. This matrix is used to construct the diffusion variable:

$$
D_{5 i t}=\sum_{\tau=t-3}^{t-1} \sum_{j=1}^{J} S_{j \tau} a_{i j}
$$

\footnotetext{
${ }^{19}$ Myers (2001) pioneers a sophisticated method of empirically deriving the decay function, dividing (i) the distribution of distances between all cases with an event by (ii) the distribution of distances between all cases. When entered into the models, however, this decay function proved inferior to the inverse square root.
} 
Hypothesis 3 is tested using newspaper circulation. We focus on newspapers rather than broadcast media because the geographical extent of readership can be reconstructed with some precision (rather than relying on the transmission radius of a broadcast station). In addition, we can examine the content of news coverage. There are data on the circulation of each daily newspaper to every county where it reached more than 5 percent of households. To take a concrete example, the Charlotte Observer (morning edition) and News (evening) circulated to more than a dozen cities in North and South Carolina, up to 112 miles away. News of sit-ins in Charlotte should therefore have a particularly great impact on those cities. These circulation figures refer to the entire population and not the black community alone. Nevertheless, black college students tended to read white newspapers (61 percent) more than black newspapers (39 percent), and so these general circulation figures should capture the flow of news within the black community (Matthews and Prothro 1975). A matrix is created with elements $c_{i j}$ coded 1 if there was a newspaper published in city $j$ that reached more than 5 percent of the households in city $i$ 's county, and 0 otherwise. This matrix is used to construct the diffusion variable:

$$
D_{6 i t}=\sum_{\tau=t-3 j=1}^{t-1} \sum_{j=1}^{J} S_{j \tau} c_{i j}
$$

For both diffusion variables, a duration of three days is adopted after testing alternatives (including seven days).

\section{RESULTS}

The event-history models are estimated using rare-events logistic regression (King and Zeng 2001) because the probability that a sit-in would occur for the first time in a particular city on a certain day is very low $(66 / 18,990=.0035)$. For ease of interpretation, the odds ratio (the exponent of the coefficient) is reported. Because the hazard is so low, the odds ratio conveniently measures how much an increase of one unit in the independent variable would multiply the probability of a sit-in —on each day, for a city in which sit-ins had not occurred. We also report (as is customary) hypothesis tests even though the data constitute the population rather than a sample. Statistical inference helps us to decide whether an observed pattern could have been produced by chance alone, or whether that is so unlikely that we are justified in attributing a causal relationship (Fox 1997:12). Standard errors are estimated without assuming that observations from the same city on different days are independent. ${ }^{20}$ The model's overall ability to discriminate between spells with the event and spells without is measured by the area under the Receiver Operating Characteristic (ROC) curve, which can range from .5 (no discrimination) to 1 (perfect discrimination). ${ }^{21}$ For comparison, a minimal model with only two control variables - black population and the day of the week-yields an ROC area of .789. Table 2 reports the results; Model 1 includes all variables, while Model 2 drops the diffusion variable derived from intercollegiate athletics.

There are mixed results for movement organizations (Hypothesis 1). The membership of NAACP had no discernible effect, nor did the presence of a Youth Council. ${ }^{22}$ The presence of an SCLC affiliate is estimated to have had a sizeable effect, though it is not statistically significant at the .05 level. The same holds for the presence of an NAACP College Chapter in Model 1. Because the variable is correlated with intercollegiate associations, Model 2 provides a better estimate. ${ }^{23}$ The effect increases in magnitude and attains statistical significance. CORE had the greatest effect of all. (Note, however, that we cannot reject the hypothesis that SCLC, CORE, and NAACP College Chapters all had the same effect.) These results suggest that protest was indeed orchestrated by some movement organizations. The mass membership of NAACP, however, does not seem to have been important; nor does SCLC have the prominence attributed to it by some scholars.

\footnotetext{
${ }^{20}$ Models are estimated using the ReLogit package for Stata (Tomz, King, and Zeng 1999), specifying the cluster option.

${ }^{21}$ Rare-events logistic regression is not a likelihood technique, and so the log likelihood is not reported.

${ }^{22}$ Expressing NAACP membership as a proportion of black population also has no significant effect. This negative finding holds even if the variables for Youth Council and College Chapter are omitted.

${ }^{23}$ The two variables are modestly correlated $(r=$ .27 ), as both indirectly reflect the presence of a college.
} 
Table 2. Determinants of the Hazard of a City's Initial Sit-in

\begin{tabular}{|c|c|c|c|c|c|c|}
\hline \multirow[b]{2}{*}{ Rare events logistic regression } & \multicolumn{3}{|c|}{1} & \multicolumn{3}{|c|}{2} \\
\hline & Odds & SE & $p$ & Odds & SE & $p$ \\
\hline Black unskilled \% & .950 & .021 & $.02 *$ & .948 & .022 & $.02 *$ \\
\hline Black unemployed \% & .908 & .043 & $.04^{*}$ & .909 & .043 & $.04 *$ \\
\hline Black college students (logged) & 1.884 & .252 & $.00 * * *$ & 1.915 & .251 & $.00^{* * *}$ \\
\hline Presence of Southern Regional Council & 1.401 & .551 & .39 & 1.404 & .552 & .39 \\
\hline Black $\%$ of county & 1.023 & .018 & .21 & 1.022 & .019 & .22 \\
\hline Black $\%$ of county (squared orthogonal) & .998 & .001 & .06 & .998 & .001 & .06 \\
\hline Poll tax in state & .522 & .166 & $.04^{*}$ & .523 & .166 & $.04^{*}$ \\
\hline Deep South & .128 & .046 & $.00 * * *$ & .129 & .046 & $.00 * * *$ \\
\hline Black population (logged) & 1.148 & .262 & .55 & 1.132 & .257 & .59 \\
\hline NAACP members $(\sqrt{ })$ & .984 & .011 & .15 & .985 & .011 & .18 \\
\hline NAACP Youth Council & 1.386 & .513 & .38 & 1.366 & .506 & .40 \\
\hline NAACP College Chapter & 1.997 & .760 & .07 & 2.141 & .783 & $.04 *$ \\
\hline SCLC affiliate & 1.995 & .739 & .06 & 1.938 & .710 & .07 \\
\hline CORE Chapter & 2.915 & 1.163 & $.01 * *$ & 2.883 & 1.123 & $.01 * *$ \\
\hline D1: Sit-ins within 7 days & .739 & .058 & $.00 * * *$ & .733 & .058 & $.00 * * *$ \\
\hline D2: Sit-ins within 7 days by distance $(\sqrt{ } \times 10)$ & 1.068 & .167 & $.00 * * *$ & 1.933 & .302 & $.00^{* * *}$ \\
\hline D3: Sit-ins before 7 days & .960 & .020 & $.05^{*}$ & .960 & .019 & $.05^{*}$ \\
\hline D4: Sit-ins before 7 days by distance $(\vee \times 10)$ & 1.297 & .091 & $.00 * * *$ & 1.293 & .089 & $.00 * * *$ \\
\hline D5: Sit-ins within 3 days if same athletic affiliation & 1.232 & .248 & .30 & & & \\
\hline D6: Sit-ins within 3 days if newspaper circulates & 2.986 & 1.281 & $.01^{*}$ & 2.882 & 1.232 & $.01^{*}$ \\
\hline W: Thursday/Friday/Saturday & 1.718 & .443 & $.04^{*}$ & 1.72 & .44 & $.03 *$ \\
\hline ROC area & & .945 & & & .944 & \\
\hline
\end{tabular}

Note: $\mathrm{N}=18,990$ city-days (excluding Sunday). Odds = odds ratio; $\mathrm{SE}=$ robust standard error.

${ }^{*} p<.05 ;{ }^{* *} p<.01 ;{ }^{* * *} p<.001$ (two-tailed tests).

The diffusion variables reveal that recent events in nearby cities had the greatest impact. $\left(D_{1}\right.$ and $D_{2}$ cannot be interpreted individually because the occurrence of another sit-in affects both simultaneously; the same is true for $D_{3}$ and $D_{4}$.) Diffusion did not follow athletic intercollegiate networks (Hypothesis 2). This variable is therefore dropped from Model 2. By contrast, newspaper circulation (Hypothesis 3) had an important effect. The initiation of a sit-in in the headquarters of a newspaper with wide circulation had a greater impact on cities within its circulation area, in the following three days. This finding need not indicate that newspapers were more important than broadcast media, as the transmission networks for radio and television may have been similar in coverage. The finding is compelling evidence, however, for the importance of news media.

Sit-ins were much more likely to occur where there were many black college students (Hypothesis 4). The size of the black population, by contrast, had no effect. Sit-ins were less likely where many blacks were relegated to unskilled occupations or were unemployed (Hypothesis 5). Political opportunities (Hypothesis 6) were clearly important. Sit-ins were less likely in states that imposed a poll tax, and much less likely in the Deep South. The percentage of blacks in the county appears to have had a non-monotonic effect (though neither term is statistically significant at the .05 level), with sit-ins being most likely where blacks constituted about one third of the population.

The magnitude of these effects (using Model 2) can be expressed by considering the "typical" city, with median values on all variables (the mode for dichotomous variables). The typical city has no movement organizations except a branch of the NAACP. The hazard of an initial sit-in is $.0022 .{ }^{24}$ Establishing a CORE Chapter

\footnotetext{
${ }^{24}$ Hazards are calculated using the ReLogit package, in the same manner as Clarify (King, Tomz, and Wittenberg 2000). The median for cross-sectional variables is calculated with each city having equal weight (not the risk-set, though using the latter makes minimal difference). The median for time-
} 


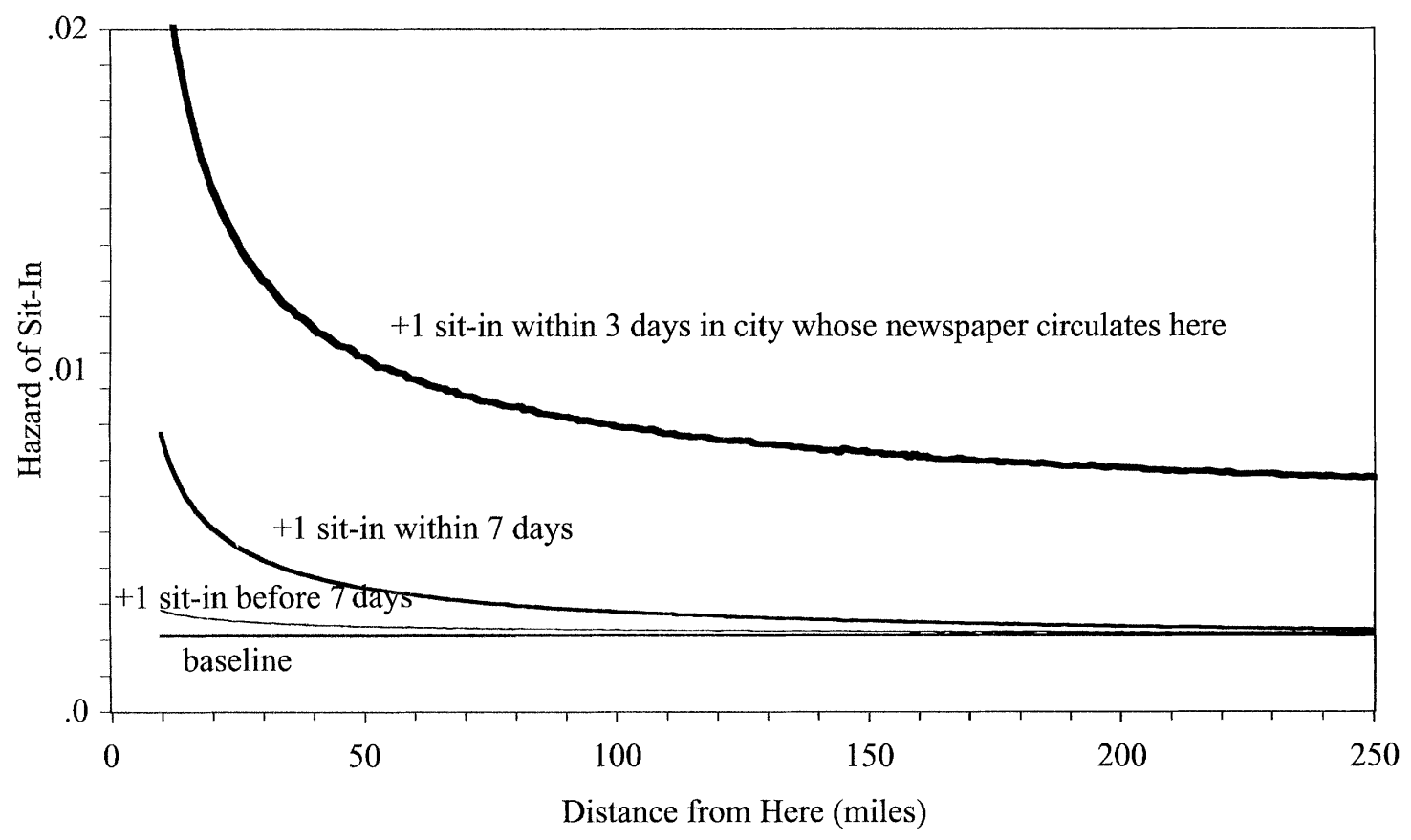

Figure 3. How the Hazard of a Sit-In Increased When Sit-ins Began in Another City

would almost triple the hazard to .0064 , an NAACP College Chapter would more than double it to .0048 , and an affiliate of SCLC would almost double it to .0043 (though the latter is not statistically significant at the .05 level). By comparison, increasing the number of black college students from 16 to 425 (the 90th percentile) would increase the hazard of a sit-in almost nine-fold, to .0197 .

Figure 3 depicts the estimated hazard of a sitin for this typical city. The diffusion variables begin at the median for cities in the risk-set: six cities had initiated sit-ins within the last seven days, and 27 cities had initiated sit-ins before then. The baseline hazard (.0022) is shown by the horizontal line. Consider first the impact of recent events. What would happen if another city initiated sit-ins, raising the number of recent events to seven? If the other city published a newspaper that circulates here, then the boldest curve shows how the hazard would be increased - even 250 miles away, the hazard would triple. ${ }^{25}$ The more usual case, where no newspaper circulates,

varying variables is calculated from the risk-set, except the control variable for Thursday/Friday/ Saturday, which is set to 1 .

${ }^{25}$ The impact diminishes with distance, of course, because the sit-in has an effect via $D_{1}$ and $D_{2}$ as well as via $D_{6}$. is depicted by the next curve. If the event had occurred 10 miles away, then the hazard would nearly quadruple to .0082 ; if a hundred miles away, then the hazard would increase by a third, to .0029 . The median distance between cities was about 500 miles: at such far remove, of course, the hazard would not increase. Consider finally the enduring impact of earlier events. The lower curve shows how the hazard would change if a sit-in had occurred over seven days earlier in one more city (raising the total to 28). The impact is relatively slight, though still noticeable. It again diminishes with distance.

In sum, then, event-history analysis reveals why sit-ins occurred in some cities rather than others, and how protest spread across the South. Sit-ins were most likely where there were many black college students (Hypothesis 4), where the black community had relatively more autonomy and resources (Hypothesis 5), and where political opportunities were less unfavorable (Hypothesis 6). In other words, protest occurred where oppression was least severe. Protest was orchestrated by movement organizations (Hypothesis 1), though what mattered was a cadre of activists rather than a large membership. ${ }^{26}$ Potential protesters were clearly inspired

\footnotetext{
${ }^{26}$ We have also tested a variant of Hypothesis 1, in which the presence of an organization enhanced
} 
by previous sit-ins, predominantly by what happened in neighboring cities. There is no positive evidence for social networks as a channel of diffusion (Hypothesis 2), but the news media was clearly important (Hypothesis 3 ).

\section{ANALYSIS OF NEWSPAPER COVERAGE}

We have seen that the initiation of protest in one city had a greater impact on nearby cities, and had its greatest impact within seven days. Hypothesis 3 implies that this spatial and temporal pattern reflected the pattern of news coverage. In other words, potential protesters were more likely to take inspiration from sit-ins in nearby cities because such events were more likely to be reported by their local news media. This implication can be tested by examining newspaper coverage of the sit-ins.

We compiled complete coverage from four major newspapers: Atlanta Constitution, Charlotte Observer, Houston Chronicle, and Miami Herald. For every day from February 1 to April 14, we coded whether a city's sit-in campaign was mentioned in each newspaper. Consider an article stating that "Concord became the ninth North Carolina city touched by the movement Friday, and students followed the same pattern moving into four Rock Hill, S.C., business establishments. Demonstrations have also spread to DeLand, Fla., and Hampton, Va." (Charlotte Observer 1960:1). The four named cities are coded as being mentioned. Besides reports of sit-ins, we included reports of negotiations, boycotts, and other events related to a city's sit-in campaign. Each newspaper mentioned a substantial fraction - from half to three-quarters — of the 66 cities with sit-ins during the period. This coverage was clearly sufficient to convey the extent of the wave.

the "susceptibility" to events in other cities (Strang and Tuma 1993), by creating interaction terms between the number of recent events $\left(D_{1}\right)$ and the dichotomous variables for organization. None of these coefficients is significantly different from zero; moreover, none of the coefficients for organization is statistically significant. In other words, the data do not allow us to discriminate between the main effect and any interaction effect. Testing whether college students enhanced susceptibility to events elsewhere produces the same indeterminate result.
Whether newspapers were more likely to report events in nearby cities can be investigated using event-history analysis. Here the "event" is a news report of another city's sit-in campaign. The dependent variable is $M_{n j t}$, coded 1 if newspaper $n$ mentioned a sit-in campaign in city $j$ at time $t$, and 0 otherwise. A campaign is "at risk" of being mentioned on each day after the initial sit-in. To take an example, Greensboro enters the risk-set every day from February 2 onward, and each day yields four cases, one for each newspaper. Excluding newspapers reporting on their own cities, there are 11,059 cases (newspapercity-day). We are interested in the hazard rate:

$$
q_{n j t}=\operatorname{prob}\left(M_{n j t}=1 \mid \sum_{\tau=1}^{t-1} S_{j \tau}=1 \wedge n \neq j\right)
$$

The model to be estimated is a variant of logistic regression:

$$
\begin{gathered}
\ln \left(\frac{q_{n i t}}{1-q_{n j t}}\right)=\beta_{0}+\beta_{1} \ln P_{j}+\beta_{2} d_{n j}+\beta_{3} d_{n j}{ }^{2}+ \\
\beta_{4} d_{n j}{ }^{3}+\beta_{5} d_{n j}{ }^{4}+\beta_{6} \sum_{\tau=t-7}^{t-1} S_{j \tau}
\end{gathered}
$$

where $\beta$ are coefficients to be estimated. Because events in larger cities are more likely to be reported, the city's population $\left(P_{j}\right)$ is controlled. The distance from the newspaper's headquarters to the city $\left(d_{n j}\right)$ is entered as a four-degree polynomial. A dichotomous variable is coded for whether the city's initial sit-in occurred within seven days.

Results are depicted in Figure 4, which shows the probability of a newspaper reporting a city's sit-in campaign on a given day. As expected, coverage is most likely within seven days of the city's initial sit-in. Most importantly, coverage diminishes significantly with distance. This echoes the pattern evident in Figure 3, though the decline with distance is less pronounced in Figure 4 . That sit-in campaigns in nearby cities were more likely to be reported in the local news media therefore helps to explain why nearby events had a greater impact. Faraway events had a lesser impact (in part) because potential protesters were less likely to learn about them from their local news media. This finding complements the finding that the diffusion of protest tended to follow the circulation of newspapers. When a newspaper circulated to other cities, then protesters in those cities would more readily learn about sit-ins in the newspaper's headquarters; otherwise, they would have to rely on coverage in their own local media. 


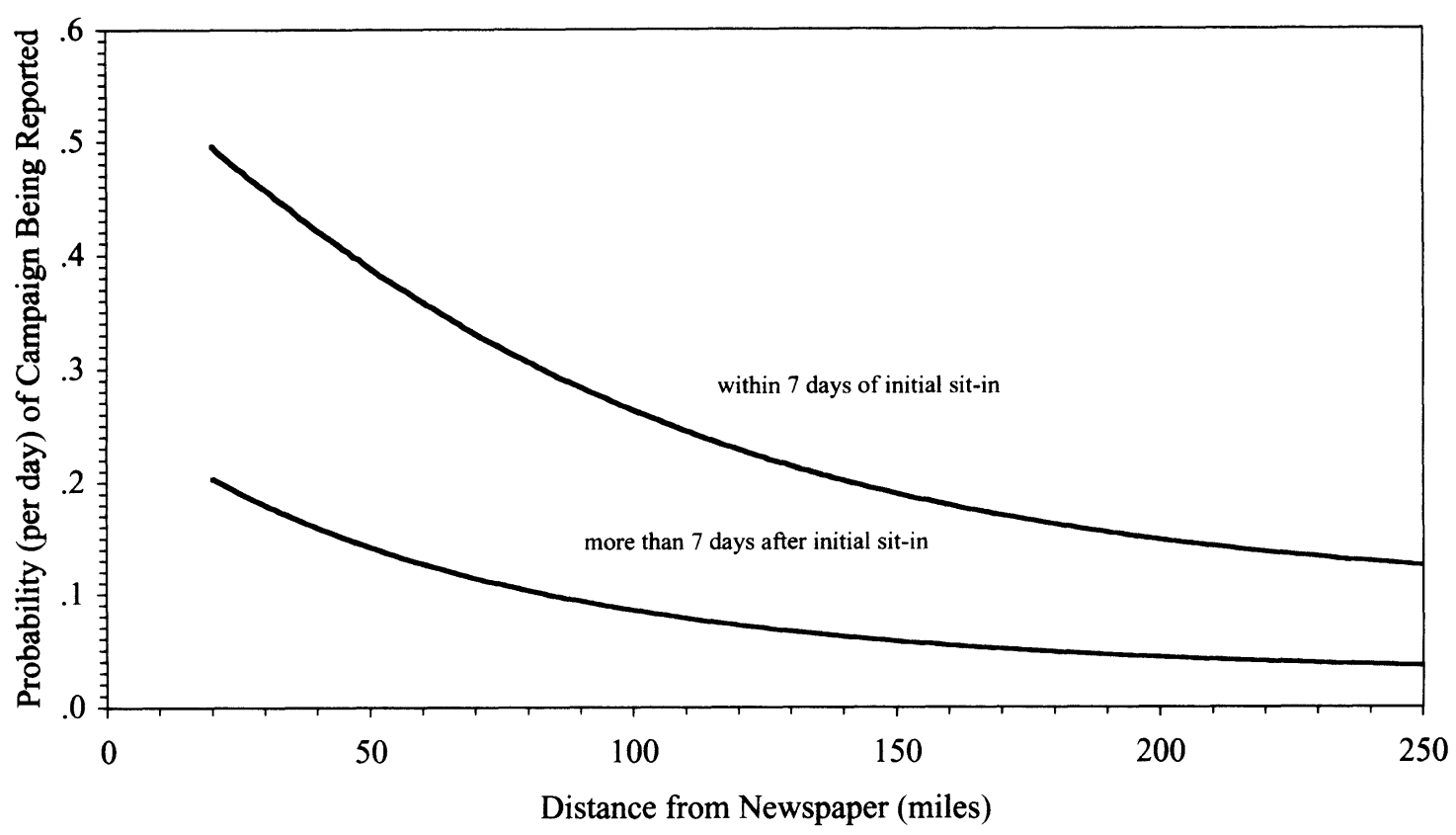

Figure 4. The Probability of a Sit-In Campaign Being Reported in a Daily Newspaper

\section{QUALITATIVE EVIDENCE ON DIFFUSION}

We turn now to qualitative evidence on the process of diffusion, drawn from contemporaneous organizational records and from participants' retrospective accounts. We consider first movement organizations, and then social networks and news media.

\section{MOVEMENT ORGANIZATIONS}

In what ways did movement organizations orchestrate protest? Our quantitative analysis demonstrates that the conventional measure of organizational strength - the number of members-was not important. Instead, what mattered was a cadre of activists, whether associated with CORE, an NAACP College Chapter, or (perhaps) SCLC. The "presence" of these organizations indicated a network of people committed to the movement against racial oppression. A well-known example is the workshop on nonviolence established by the Nashville Christian Leadership Council (affiliated with SCLC), led by Reverend James Lawson. A handful of students from the city's institutions of higher education began attending the workshop in the fall of 1959 (Halberstam 1998; Wynn 1991). John Lewis, from the American Baptist Theological Seminary, recalled "a very small group" (Powledge 1991:205). Although this group provided crucial leadership, Lewis noted that "about ninety to ninety-five percent of the people who showed up at the church the week before [the first sitin] had no training in nonviolence ... but they were ready to go" (Viorst 1979:107). In Winston-Salem, North Carolina, the sit-ins were led by a recent graduate of the Teachers' College, who was on the executive board of the local NAACP branch (Bryan 2000; NAACP 1960; Patrick 1960). ${ }^{27}$ Protesters came from the NAACP College Chapter-with 270 members in 1959, it was the largest in the South (the median was 64). Tallahassee's first sit-ins were conducted by a Chapter of CORE that had been established in October 1959, thanks to the efforts of two sisters from the Agricultural and Mechanical College. It counted just 18 duespaying members (Rabby 1999:86).

\footnotetext{
${ }^{27}$ Morris (1984: 200) contends that in Durham and Winston-Salem, "McKissick, Moore, Carey, and others helped organize those protests by bringing students from local colleges to churches, where they were trained to conduct sit-ins. ... Following training and strategy sessions, the students went to the local lunch counters and sat in." Detailed accounts of events in Winston-Salem and Durham suggest that student leadership and initiative was more crucial (Bryan 2000; Dalton 2001; Gallo 1978; Howard 1983; Greene 2005; Patrick 1960; Sindler 1965).
} 
We should not overlook cases where movement organizations were less successful or were not necessary. Indeed, ten cities with SCLC affiliates had no sit-ins throughout this period, including New Orleans, Mobile, and Louisville (Gaillard 2004; Fairclough 1995). In New Orleans, Reverend A. L. Davis led the city's Interdenominational Ministerial Alliance and belonged to SCLC's executive board. Yet the city had no sit-ins: students at Dillard University were dissuaded by the threat of expulsion (Fairclough 1995; Rogers 1993). Conversely, there were six cities where sit-ins occurred despite the absence of any movement organization (including an NAACP branch) such as Elizabeth City, North Carolina.

On balance, of course, the presence of a local cadre of activists did make sit-ins more likely. Did these local activists act on their own initiative, or were they responding to directions from the staff and leaders of their organizations? Even before the sit-ins had spread beyond Greensboro, the local NAACP president asked CORE's national office (in New York) for help. CORE immediately dispatched two field secretaries, Gordon Carey and James McCain, to aid the protesters. Given NAACP's ambivalence about confrontational protest, the organization was also surprisingly quick to respond: the youth secretary, Herbert Wright, traveled from New York to North Carolina, where he was assisted by the state's field secretary, Charles McLean. Within SCLC, Reverend Fred Shuttlesworth and Reverend Douglas Moore were particularly enthusiastic, although the organization lacked any equivalent paid organizer. ${ }^{28}$ Within two weeks, then, all three movement organizations were actively involved.

In most cases, outside support followed rather than preceded protest in a given locality. McLean reported that the sit-ins in North Carolina "were spontaneous, but after they started the student leaders turned to the NAACP for advice, legal assistance, necessary funds and assistance to carry on the protest" (NAACP 1960:15). Similarly, protesters could ask CORE's field secretaries or SCLC's ministers to come and provide practical training in nonviolence. Outside help was not always welcome,

${ }^{28}$ SCLC only hired a field secretary after the wave of sit-ins (Fairclough 1987). however. The student leader at Charlotte's Johnson C. Smith University, Charles Jones, refused help from NAACP and publicly rebuked CORE's Carey (NAACP 1960:7; Oppenheimer 1963:180; Wehr 1960:29). "We are willing to listen to what people like him [presumably Carey] have to say," another leader warned, "but we are going to keep control of this thing ourselves" (Wehr 1960:28). Even Carey acknowledged that the "'outside agitators' were being pulled along by the kids. It was purely spontaneous.... [W]e were not leaders; we were followers" (Powledge 1991:214). Morris $(1981,1984)$ implies that Baker coordinated protest from SCLC's headquarters in Atlanta. In fact, her achievement was to encourage students already involved in the sit-ins to organize at the regional level, at the Easter conference held at Shaw University. As she recalled, "[T] here was little or no communication between those who sat in, say, in Charlotte, North Carolina, and those who sat in at some other place in Virginia or Alabama. They were motivated by what the North Carolina four had started, but they were not in contact with each other" (Cantarow 1980:83).

The activity of movement organizations was surely vital for sustaining the sit-in campaignsbut this should not be confused with the orchestration of protest in cities where it had not yet occurred. There are surprisingly few instances of organizers initiating protest in other cities. Moore attempted to broaden the protest beyond North Carolina by calling Lawson in Nashville on February 10 (Wynn 1991:45). ${ }^{29}$ Despite Moore's prodding, Lawson and the head of the Nashville Christian Leadership Council were cautious, and they tried to persuade students in the workshop to delay protest. The riposte by a student at American Baptist seminary is well known: "I am sick and tired of waiting!" (Morris 1984:206). CORE provides less ambiguous instances of orchestration from outside. McCain called members in Tallahassee, encouraging them to begin protest on February 13 (Rabby 1999:88). The city's first sit-in occurred on that

\footnotetext{
${ }^{29}$ Some accounts (Branch 1988; Halberstam 1998; Morris 1984) place this telephone call earlier in the week, on the basis of retrospective interviews. The 10 th is attested by a contemporary report in the Tennessean, quoting Lawson (see Sumner 1989) and by Paul Laprad (reproduced in Peck 1962:64).
} 
date. A visit by McCain to Orangeburg, South Carolina, also seems to have orchestrated protest, even though the city lacked a CORE Chapter; the nearest was 37 miles away (Morris 1984:201; Meier and Rudwick 1973:104). ${ }^{30}$

Overall, then, movement organizations did facilitate protest, but the diffusion of sit-ins depended more on the existence of a cadre of local activists before February 1 than on the subsequent activities of organizational staff and leaders. Those activities were crucial for sustaining protest once it had begun, of course. Movement organizations also applied additional pressure on department stores. CORE led a boycott and protest campaign in Northern cities, and NAACP belatedly endorsed a general boycott in mid-March. Focusing on the initiation of protest, however, we see that local activists were responding above all to sit-ins occurring elsewhere.

\section{SOCIAL NETWORKS AND NEWS MEDIA}

Our quantitative analysis suggests that information about protest elsewhere was conveyed by news media rather than social networks. Although that finding depends on a proxy measure for networks, it is reinforced by qualitative evidence. Wehr (1960:25) discovered "little if any contact and no real liaison" among protesters at different cities in North Carolina. Clearly sit-ins were facilitated by friendships among students within a college, and friendships among students at different colleges in the same city. There is a surprising lack of evidence, however, for social networks acting as channels for the diffusion of protest among cities. In contemporary accounts and retrospective interviews, we have found no examples of protesters being informed of sit-ins by personal acquaintances elsewhere.

By contrast, several protesters mentioned that they first heard of events elsewhere from the news media. When a reporter in Chattanooga asked a protester where the idea of a sit-in originated, he replied: "[W]e read the papers. We got our ideas from other people" (Atlanta Constitution 1960:2). In Atlanta, Lonnie King,

\footnotetext{
${ }^{30}$ In this instance, the positive effect of movement organization is not captured by our eventhistory analysis.
}

a student at Morehouse College, read about the Greensboro sit-ins in the Atlanta Daily World, a black newspaper. He took the article to a fellow student, Julian Bond, asking, "Don't you think it should happen here?" (Raines 1977:84). The two went on to lead the sit-ins in Atlanta. Broadcast media were also important. In the same city, Ruby Doris Smith at Spelman College watched the Greensboro sit-ins on television: "I began to think right away about it happening in Atlanta" (Zinn 1964:17, see also Sitkoff 1993; Tyson 2004). Jones, the student who led the sitin in Charlotte, heard about Greensboro on his car radio. "All of a sudden," he recalled, "there was a handle to getting at this stuff" (Powledge 1991:224). Contemporary studies likewise emphasize the importance of news media. According to Oppenheimer (1963:62), "[T]he most common source of information is attributed by students to the radio and newspapers" (see also Wehr 1960:25; Laue 1966:81). The importance of the media is compatible with Lazarsfeld's two-step flow of communication, whereby the mass media influences "opinion leaders," who then transmit ideas more broadly through personal contact (Lazarsfeld, Berelson, Gaudet 1968; Katz and Lazarsfeld 1955). Diffusion among cities corresponded to the first step as opinion leaders like King in Atlanta and Jones in Charlotte learned of protest elsewhere, while the mobilization of students within each city corresponded to the second step of communication through personal networks.

The news media did not, of course, intend to encourage protest. Some white newspapers were sympathetic to the goals of the sit-ins, but they invariably opposed the tactic - as indeed did some black newspapers, including the Atlanta Daily World (Walker 1964). What mattered was not editorial endorsement but rather information about protest elsewhere (as the example of King illustrates). Information, most basically, made potential protesters aware of this novel tactic. Awareness was rarely enough, or else the sit-ins would have all been initiated after the first reports of events in Greensboro. Potential protesters were naturally cautious about directly confronting the system of racial oppressionrisking violence, arrest, and expulsion from college. The relevance of Greensboro was questionable for those who faced far greater oppression in the Deep South; students in Birmingham 
actually waited over six weeks to initiate sit-ins despite encouragement from SCLC's Shuttlesworth (Manis 1999). What was crucial, we argue, was information about the extent of the wave. Quantitative analysis shows how the hazard of a sit-in increased as additional cities were swept up in the wave. The effect was expressed by Peace, a student leader in Raleigh, on February 9, after the wave had reached three cities (and would encompass two more by day's end). "The damned thing is spreading all over the place and we haven't made a move yet" (Mitchell 1962:75). Raleigh's sit-ins began on the following day.

Scrutiny of qualitative evidence, along with analysis of newspaper coverage, strengthens our confidence in the event-history analysis and enhances our understanding of the results. These various sources of evidence provide a clear picture of the diffusion of sit-ins in the spring of 1960 . Blacks, predominantly college students, initiated sit-ins because they were inspired by previous sit-ins in other cities. Information about events elsewhere came primarily from news reports. As they learned about the increasing number of sit-ins, especially in cities nearby, potential protesters became more optimistic about the prospect of success-not, it should be reiterated, because success was evident, but simply because so many others were initiating sit-ins. Local activists, primarily students and ministers, played an important role in orchestrating protest. Although the leaders of all three movement organizations had a modest impact on the spread of protest, they contributed to realizing the potential of the sit-ins by providing financial assistance and training once protest was initiated.

\section{CONCLUSION}

By the middle of April 1960, the movement against racial oppression had been transformed. Tens of thousands of blacks in the South had physically challenged segregation; black college students, previously politically quiescent, were now in the vanguard of the movement. Nonviolent protest increased in intensity as well as extent; students arrested during a sit-in in Tallahassee staged the first jail-in (by refusing bail) in March. In the following year, a group of CORE activists traveled through the South on interstate buses setting off another tactical innovation - the Freedom Ride-which was replicated over 60 times in 1961 (Arsenault 2006). Following the sit-ins, SCLC also shifted its strategy to intensive protest, most notably in Albany in 1961-62 and in Birmingham in 1963. These campaigns represented the tip of the iceberg as black communities throughout the South organized local campaigns using more confrontational tactics. In 1963 alone the Southern Regional Council identified 930 demonstrations in 115 cities in the South with over twenty thousand arrests (Heacock 1965). In short, "the sit-ins revitalized all of the major civil rights organizations, led to the creation of SNCC, reinforced a tactic that was to dominate the movement in the next few years, and generally set the black struggle in motion once again" (McAdam and Sewell 2001:108).

Corresponding to their historical importance, the 1960 sit-ins are frequently cited in the literature on social movements. We have analyzed one dimension of this wave of protest, the diffusion of sit-ins to cities across the South. Our analysis involved systematic comparison of cities swept up in the wave with those that remained untouched, and detailed attention to the timing of events. Findings from the eventhistory analysis of diffusion have been amplified by evidence from contemporary sources and retrospective interviews, along with a systematic analysis of news reports.

The debate over "organization" (Morris 1981, 1984) versus "spontaneity" (Killian 1984; Oberschall 1989) can now be resolved. Both sides are partly correct. On one hand, movement organizations were undoubtedly important. They were central in coordinating and sustaining protest campaigns once they were underway. As for the initiation of protest, the presence of a CORE Chapter or NAACP College Chapter at least doubled the chance of a sit-in. The effect for SCLC was of similar magnitude, though this estimate is more uncertain. On the other hand, the sit-ins cannot simply be attributed to formal movement organizations. Most cities with organization (including NAACP branches) did not have sit-ins; some sit-ins occurred in the absence of any organization. The best predictor of protest was the number of black college students. Moreover, the main channel of diffusion was the media. Protest spread because blacks 
were inspired by the actions of others elsewhere, which they usually learned about from news reports. In this sense, the sit-ins were "spontaneous" rather than organized by the leaders of movement organizations.

By concentrating on the rapid diffusion of protest in the course of months, we have not addressed the broader question of timing: why did the wave of sit-ins occur in 1960 rather than some years before or after? The upsurge in protest in 1960 cannot be predicted by long-term social and political changes. This can be shown using a recent time-series analysis of black protest from 1947 to 1998 (Jenkins et al. 2003). Independent variables include NAACP membership, various measures of grievances, such as black unemployment, and various measures of political opportunities, such as the power of non-Southern Democrats. Replicating this analysis, we find that slightly more protest events are predicted in the late 1950s than in the early 1950s. Nevertheless, the upsurge in 1960 is not predicted; the residual for that year is huge (results available from authors). This failure to predict 1960 using annual intervals and aggregate measures of political opportunity and organization underscores the need for more temporally and spatially refined analysis.

Our findings suggest several explanations for the timing of this wave of protest. First, movement organizations increased their presence in the late 1950s: SCLC was established, CORE began to spread to the South, and NAACP College Chapters were founded. What mattered was not the growth of mass membership (as measured by Jenkins et al. 2003) but the expansion of activist cadres. Second, black colleges expanded; the number of students increased by 35 percent in the $1950 \mathrm{~s}$. The third point is more tentative. Newspapers-black as well as white-may have been less likely to report protest before the mid-1950s. After all, the leaders of the Montgomery bus boycott were ignorant of the bus boycott in Baton Rouge that had occurred just two years before (Meier and Rudwick 1976:382). The Montgomery campaign (and perhaps events in Little Rock, too) seems to have made black protest in the South more newsworthy. Finally, our analysis demonstrates how the impact of a sit-in elsewhere diminished with distance. This helps explain why sit-ins in Oklahoma City in 1958 did not spark a wave of sit-ins in the South (see also Oppenheimer 1963:53; Oberschall 1989:43). ${ }^{31}$

Our findings also illuminate another question: why did the wave of sit-ins begin in Greensboro? Was this geographical origin purely "contingent"? To answer this question empirically, we can return to Model 2 (in Table 2) and compare the estimated hazards for each city on February 1. This procedure effectively "controls for" geographical location, in a way that a crosssectional analysis would not. ${ }^{32}$ Although Greensboro does not have the highest estimated hazard, it ranks third behind Tallahassee and Durham. These estimates accord with historical evidence. Activist cadres in those two cities had conducted "test" sit-ins in 1958 or 1959, and students in Tallahassee were actively preparing for a sit-in campaign at the beginning of 1960 (Killian 1984; Morris 1984). Similar preparations were under way in Nashville (Halberstam 1998), which ranks fourth. Estimated hazards vary by many orders of magnitude: the hazard is about two thousand times higher for Tallahassee than for the median city, and two hundred thousand times higher than for the city with the lowest hazard. The action of four students in Greensboro on February 1 was contingent in the sense that it is easy to imagine a wave of sit-ins starting instead in Tallahassee, for example - but not in the sense that sit-ins were likely to have been initiated anywhere in the South.

Before turning to the broader implications for research on the diffusion of protest, we should acknowledge the particular characteristics of this historical episode. Most important was that racial oppression in the South - enforced by law as well as norms - created an inescapable collective identity. Therefore when blacks challenged white supremacy in one place, blacks elsewhere in the South could more readily iden-

${ }^{31}$ The nearest city with a sit-in in 1960 - Little Rock, Arkansas-is about 200 miles away from Oklahoma City.

32 Some cities (like Portsmouth, Virginia) were surrounded by other cities where conditions were conducive to protest, while others (like Austin, Texas) were relatively isolated. By explicitly modeling spatial diffusion variables, we can disentangle characteristics of a city and its geographical location. 
tify with their actions. The attribution of similarity was even more pronounced among black college students. These were unusually fruitful conditions for the rapid diffusion of protest. Many other social movements lack such preexisting cultural conditions for mobilization (Morris and Braine 2001). Characteristics of the tactic itself may have enhanced the possibility of diffusion. Although extended sit-in campaigns required planning and coordination, a sit-in could be initiated by a handful of activists possessing nothing more than enthusiasm and courage. Despite these particular characteristics of the sit-ins in 1960, our analysis has two important implications-regarding organization and media - for the literature on social movements.

Our findings confirm the significance of movement organizations, but they also highlight crucial differences among types of organization and specify how organization mattered. NAACP was extraordinarily strong, with mass membership and considerable resources. CORE, by contrast, was weak; in 1959, its income was only 7 percent of NAACP's (McAdam 1982:253; Marger 1984:23). Despite the disparity, CORE played the more important role in propagating the sit-ins (see also Ganz 2000). Moreover, NAACP's contribution to the sit-ins came more from the actions of members in College Chapters (and decisions of local branches to support protest) than from the decisions of the organization's national leadership. Movement organizations were important insofar as they incubated local cadres of activists; such activists were ready to take advantage of protest occurring elsewhere and did not have to wait for orders from above. Future research should develop a more nuanced understanding of the relationship between formal organization and collective protest.

By emphasizing the importance of news media, our findings warn against the tendency to assume that relational channels of diffusionhere differentiated into formal organization and informal networks - are inevitably more important than non-relational channels (in a different context, see Van den Bulte and Lilien 2001). Mobilization on the local level depends on social networks, but the diffusion of protest between locales may depend on information transmitted by the media. This should not be surprising. Recent studies have also demonstrated the importance of media, either by tracing the physical transmission of information (Myers 2000) or by analyzing the information itself (Koopmans and Olzak 2004). Here we have done both (like Roscigno and Danaher 2000), looking at the geographical circulation of newspapers and the content of news reports. The findings of our analysis and other recent studies also raise important questions about longterm historical change. Social movements and protest waves have been shaped by the mass media, more than we have hitherto appreciated. Therefore changes in media technologies and institutions have important implications. Whether new communication technologies - the Internet and cell phones - are beginning to supplant the mass media-newspapers, radio, and television-is a question for studies of contemporary protest waves.

Most studies of protest focus on the longer development of protest cycles (Koopmans 1993; Oliver and Myers 2003; Tarrow 1998). We have made the case for studying the spread of confrontational protest forms over a relatively short time period where new insights regarding protest dynamics can be revealed (Koopmans 2004; McAdam, Tarrow, and Tilly 2001). This is motivated by the expectation that periods of rapid diffusion have transformative effects on the development of social movements (McAdam and Sewell 2001). Further analysis is needed to determine whether and, if so, how moments like the spring of 1960 shape the trajectories of individual activists; the goals, leadership, and resources of movement organizations; the mobilization and strategies of opponents; and the attainment of movement goals at the community or national level.

Kenneth T. Andrews is Assistant Professor of Sociology at the University of North Carolina at Chapel Hill. His research focuses on social movements, political institutions, and social change. His recently published book-Freedom is a Constant Struggle: The Mississippi Civil Rights Movement and Its Legacy (University of Chicago Press, 2004) examines the influence of the civil rights movement on electoral politics, school desegregation, and social policies. Other current projects investigate organization and leadership in contemporary movements, including a study of the environmental sector in North Carolina and a national study of the Sierra Club's state and local organizations. 
Michael Biggs is lecturer in Sociology at the University of Oxford. A companion article on the sit-ins, which examines the determinants of individual participation, will appear in Mobilization. Previous research on the dynamics of protest, investigating the strike wave in Chicago in 1886, has appeared in American Journal of Sociology, Theory and Society, and Social Science History. He has begun research on self-inflicted suffering as a means of protest; an essay on self-immolation is included in Making Sense of Suicide Missions (Oxford University Press, 2005).

\section{APPENDIX: EXPLANATORY VARIABLES}

Table A1. Independent Variables

\begin{tabular}{|c|c|c|}
\hline Variable Name & Description & Source \\
\hline Black population & Nonwhite population, 1960 & U.S. Bureau of the Census 1963 , table 21 \\
\hline Black unemployed \% & $\begin{array}{l}\text { Unemployed nonwhite males / } \\
\text { nonwhite males in civilian labor } \\
\text { force, } 1960\end{array}$ & U.S. Bureau of the Census 1963, table 77 \\
\hline Black unskilled \% & $\begin{array}{l}\text { Nonwhite males in unskilled } \\
\text { occupations (private household } \\
\text { workers; service workers; farm } \\
\text { laborers excluding unpaid and } \\
\text { foremen; other laborers) / non- } \\
\text { white males in civilian labor } \\
\text { force, } 1960\end{array}$ & U.S. Bureau of the Census 1963 , table 78 \\
\hline NAACP members & $\begin{array}{l}\text { Average number of members of } \\
\text { NAACP chapter, } 1957 \text { and } 1959\end{array}$ & $\begin{array}{l}\text { NAACP Papers, Part 25, Series D, Reel 3: } \\
\text { Total } 1957 \text { Memberships and Freedom } \\
\text { Fund Contributions Received from } \\
\text { Branches; Part 25, Series D, Reel 24, } \\
\text { Total 1959 Memberships and Freedom } \\
\text { Fund Contributions Received }\end{array}$ \\
\hline NAACP Youth Council & $\begin{array}{l}1 \text { if city has NAACP Youth } \\
\text { Chapter, } 1958 \text { or } 1959\end{array}$ & $\begin{array}{l}\text { NAACP Papers, Part 19, Series D, Reel } \\
\text { 14: Total } 1958 \text { Youth Membership } \\
\text { Received; Youth and Student }\end{array}$ \\
\hline NAACP College Chapter & $\begin{array}{l}1 \text { if city has NAACP College } \\
\text { Chapter, } 1958 \text { or } 1959\end{array}$ & $\begin{array}{l}\text { Memberships Received from Region V } \\
\text { During 1959; Youth and Student } \\
\text { Memberships Received from Region } \\
\text { VI During 1959; Statement of Virginia } \\
\text { Youth Memberships }\end{array}$ \\
\hline SCLC affiliate & $\begin{array}{l}1 \text { if city has SCLC affiliate(s) or is } \\
\text { represented on the SCLC } \\
\text { Executive Board, February } 3 \text {, } \\
1960\end{array}$ & $\begin{array}{l}\text { SCLC Papers, Reel 1, Part 2: Affiliates of } \\
\text { the Southern Christian Leadership } \\
\text { Conference, Inc., February } 3,1960\end{array}$ \\
\hline CORE Chapter & $\begin{array}{l}1 \text { if city has CORE Chapter at the } \\
\text { beginning of } 1960\end{array}$ & $\begin{array}{l}\text { CORE Papers, multiple reels; Meier and } \\
\text { Rudwick 1973:83-92 }\end{array}$ \\
\hline Black college students & $\begin{array}{l}\text { Nonwhites enrolled in college, } \\
1960\end{array}$ & U.S. Bureau of the Census 1963, table 77 \\
\hline Black $\%$ of county & $\begin{array}{l}\text { Nonwhite population / total popu- } \\
\text { lation of county, } 1960\end{array}$ & U.S. Bureau of the Census 1963, table 21 \\
\hline $\begin{array}{l}\text { Presence of Southern Regional } \\
\text { Council }\end{array}$ & $\begin{array}{l}1 \text { if city has individual or organiza- } \\
\text { tion affiliated with Southern } \\
\text { Regional Council, } 1955\end{array}$ & $\begin{array}{l}\text { Southern Regional Council Papers, Reel } \\
\text { 75: State Organizations, officer lists, } \\
\text { Feb. 4, 1953-Dec. 31, 1967; SRC } \\
\text { Affiliated Organizations, } 1955\end{array}$ \\
\hline Poll tax in state & 1 if state had a poll tax & $\begin{array}{l}\text { Matthews and Prothro's Southern County } \\
\text { Data (courtesy of James Alt); Key } \\
\text { 1950; Keyssar } 2000\end{array}$ \\
\hline Deep South & $\begin{array}{l}1 \text { for Alabama, Georgia, Louisiana, } \\
\text { Mississippi, South Carolina }\end{array}$ & Black and Black 1987 \\
\hline
\end{tabular}


Table A2. Matrices for Diffusion Variables

\begin{tabular}{|c|c|c|c|}
\hline Matrix & Description & Source & $\begin{array}{l}\text { Median distance } \\
\text { between linked cities }\end{array}$ \\
\hline $\mathrm{d}_{\mathrm{ij}}$ & $\begin{array}{l}\text { Distance in miles between city } i \text { and } j \text {; dis- } \\
\text { tances }<10 \text { miles treated as } 10 \text { miles }\end{array}$ & $\begin{array}{l}\text { U.S. Geological Survey's } \\
\text { Geographic Names } \\
\text { Information System, } \\
\text { http://mapping.usgs.gov }\end{array}$ & 508 miles \\
\hline$a_{i j}$ & $\begin{array}{l}1 \text { if city i has college affiliated with same } \\
\text { intercollegiate association (Central, } \\
\text { Eastern, Gulf Coast, Midwestern, } \\
\text { Southern, South Central, or Southeastern) } \\
\text { as college in city j }\end{array}$ & $\begin{array}{l}\text { Chicago Defender, } 13 \text { Aug. } \\
1960\end{array}$ & $\begin{array}{l}210 \text { miles ( } 160 \text { city } \\
\text { pairs) }\end{array}$ \\
\hline$c_{i j}$ & $\begin{array}{l}1 \text { if newspaper published in city j reached } \\
\text { more than } 5 \% \text { of the households in city i's } \\
\text { county, for daily (morning or evening) } \\
\text { editions }\end{array}$ & $\begin{array}{l}\text { Standard Rate and Data } \\
\text { Service } 1960\end{array}$ & 47 miles (423 city pairs) \\
\hline
\end{tabular}

\section{REFERENCES}

Amenta, Edwin, Kathleen Dunleavy, and Mary Bernstein. 1994. "Stolen Thunder? Huey Long's 'Share Our Wealth,' Political Mediation, and the Second New Deal." American Sociological Review 59:678-702.

Andrews, Kenneth T. 2004. Freedom Is a Constant Struggle: The Mississippi Civil Rights Movement and Its Legacy. Chicago, IL: University of Chicago Press.

Arsenault, Raymond. 2006. Freedom Riders: 1961 and the Struggle for Racial Justice. New York: Oxford University Press.

Atlanta Constitution. 1960. "Café Push Spreads to Tennessee." February 20, p. 2.

Beck, E. M. and Stewart E. Tolnay. 1990. "The Killing Fields of the Deep South." American Sociological Review 55:526-39.

Biggs, Michael. 2003. "Positive Feedback in Collective Mobilization: The American Strike Wave of 1886." Theory and Society 32:217-54.

- 2005. "Strikes as Forest Fires: Chicago and Paris in the Late 19th Century." American Journal of Sociology 110:1684-714.

- Forthcoming. "Who Joined the Sit-ins and Why: Southern Black Students in the Early 1960s." Mobilization.

Black, Earl and Merle Black. 1987. Politics and Society in the South. Cambridge, MA: Harvard University Press.

Branch, Taylor. 1988. Parting the Waters: America in the King Years, 1954-63. New York: Touchstone.

Bryan, G. McLeod. 2000. Making History: February 23, 1960, Winston-Salem, North Carolina. Winston-Salem, NC: Wake Forest University and Winston-Salem State University.

Cantarow, Ellen with Susan Gushee O'Malley and Sharon Hartman Strom. 1980. Moving the
Mountain: Women Working for Social Change. Old Westbury, NY: Feminist Press.

Carson, Clayborne. 1981. In Struggle: SNCC and the Black Awakening of the 1960s. Cambridge, MA: Harvard University Press.

- 1986. "Civil Rights Reform and the Black Freedom Struggle." Pp. 19-32 in The Civil Rights Movement in America, edited by Charles W. Eagles. Jackson, MS, and London, England: University Press of Mississippi.

Chafe, William H. 1980. Civilities and Civil Rights. New York: Oxford University Press.

Charlotte Observer. 1960. “41 Raleigh Negroes Arrested in Protest for Food Service: N.C. Move Spreads to 9 Cities." February 13, p. 1.

Conell, Carol and Cohn, Samuel. 1995. "Learning from Other People's Actions." American Journal of Sociology 101:366-403.

Conell, Carol and Kim Voss. 1990. "Formal Organization and the Fate of Social Movements." American Sociological Review 55:255-69.

Constable, John. 1960. "Negro Student Protests Challenge N.C. Leaders." New South 15:3-10.

CORE. 1960. Cracking the Color Line: Non-Violent Direct Action Methods of Eliminating Racial Discrimination. New York: CORE.

Dalton, Mary M., director. 2001. [Videorecording] "I'm Not My Brother's Keeper: Leadership and Civil Rights in Winston-Salem, North Carolina." Winston-Salem, NC: Wake Forest University.

Dykeman, Wilma and James Stokely. 1960. "Sit Down Chillun, Sit Down!" The Progressive June: 8-12.

Egerton, John. 1995. Speak Now Against the Day: The Generation Before the Civil Rights Movement in the South. Chapel Hill, NC: University of North Carolina Press.

Eick, Gretchen Cassel. 2002. Dissent in Wichita: The 
Civil Rights Movement in the Midwest, 1954-1972. Urbana and Chicago: University of Illinois Press.

Eisinger, Peter K. 1973. "The Conditions of Protest Behavior in American Cities." American Political Science Review. 67:11-28

Fairclough, Adam. 1987. To Redeem the Soul of America. Athens, GA: University of Georgia Press. 1995. Race \& Democracy: The Civil Rights Struggle in Louisiana, 1915-1972. Athens, GA: University of Georgia Press.

\section{Penguin.}

Fox, John. 1997. Applied Regression Analysis, Linear Models, and Related Methods. Thousand Oaks, CA: Sage.

Gaillard, Frye. 2004. Cradle of Freedom: Alabama and the Movement that Changed America. Tuscaloosa, AL: University of Alabama Press.

Gallo, Elyse. 1978. "The Emergence of Direct Action: The Early Civil Rights Movement in Durham, North Carolina." Manuscript, Chris Howard Papers, Duke University, Durham, NC.

Ganz, Marshall. 2000. "Resources and Resourcefulness: Strategic Capacity in the Unionization of California Agriculture, 1959-1966." American Journal of Sociology 105:1003-62.

Gould, Roger. 1991. "Multiple Networks and Mobilization in the Paris Commune, 1871." American Sociological Review 56:716-29.

Graves, Carl R. 1981. "The Right to be Served: Oklahoma City's Lunch Counter Sit-Ins, 1958-1964." Chronicles of Oklahoma 59:152-66.

Greene, Christina. 2005. Our Separate Ways: Women and the Black Freedom Movement in Durham, North Carolina. Chapel Hill, NC: University of North Carolina Press.

Halberstam, David. 1998. The Children. New York: Fawcett.

Heacock, Ronald T. 1965. Understanding the Negro Protest. New York: Pageant.

Hedström, Peter. 1994. "Contagious Collectivities: On the Spatial Diffusion of Swedish Trade Unions, 1890-1949." American Journal of Sociology 99:1157-79.

Hedström, Peter, Rickard Sandell, and Carlotta Stern. 2000. "Mesolevel Networks and the Diffusion of Social Movements." American Journal of Sociology 106:145-72.

Howard, Chris D. 1983. "Keep Your Eyes on the Prize: The Black Struggle for Civic Equality in Durham, North Carolina, 1954-1963." Thesis, Department of History, Duke University, Durham, NC.

James, David R. 1988. "The Transformation of the Southern Racial State." American Sociological Review 53:191-208.

Jenkins, J. Craig, David Jacobs, and Jon Agnone. 2003. "Political Opportunities and African-
American Protest, 1948-1997." American Journal of Sociology 109:277-303.

Katz, Elihu and Paul F. Lazarsfeld. 1955. Personal Influence: The Part Played by People in the Flow of Mass Communications. New York: Free Press.

Key, V. O., Jr. 1949. Southern Politics in State and Nation. New York: Knopf.

Keyssar, Alexander. 2000. The Right to Vote. New York: Basic Books.

Killian, Lewis M. 1984. "Organization, Rationality and Spontaneity in the Civil Rights Movement." American Sociological Review 49:770-83.

King, Gary, Michael Tomz, and Jason Wittenberg. 2000. "Making the Most of Statistical Analyses." American Journal of Political Science 44:347-61.

King, Cary and Langche Zeng. 2001. "Explaining Rare Events in International Relations." International Organization 55:693-715.

Klarman, Michael J. 1994. "How Brown Changed Race Relations: The Backlash Thesis.” Journal of American History 81:81-118.

Koopmans, Ruud. 1993. "The Dynamics of Protest Waves: West Germany, 1965-1989." American Sociological Review 58:637-58.

—_. 2004. "Protest in Time and Space." Pp. 19-46 in The Blackwell Companion to Social Movements, edited by D. A. Snow, S. A. Soule, and H. Kriesi. London, England: Blackwell.

Koopmans, Ruud and Susan Olzak. 2004. "Discursive Opportunities and the Evolution of Right-Wing Violence in Germany." American Journal of Sociology 110:198-230.

Kriesi, Hanspeter, Ruud Koopmans, Jan Willem Duyvendak, and Marco Giugni. 1995. New Social Movements in Western Europe: A Comparative Analysis. Minneapolis, MN: University of Minnesota Press.

Laue, James H. [1966] 1989. Direct Action and Desegregation, 1960-1962. Brooklyn, NY: Carlson.

Lazarsfeld, Paul F., Bernard Berelson, and Hazel Gaudet. 1968. The People's Choice: How the Voter Makes up His Mind in a Presidential Campaign, $3 \mathrm{~d}$ ed. New York and London, England: Columbia University Press.

Lomax, Louis E. 1960. "The Negro Revolt Against 'The Negro Leaders." Harpers, June, pp. 41-48.

- 1962. The Negro Revolt. New York: Harper and Row.

Luper, Clara. 1979. Behold the Walls. Oklahoma City, OK: Jim Wire.

Maney, Gregory M. and Pamela E. Oliver. 2001. "Finding Collective Events." Sociological Methods and Research 30:131-69.

Manis, Andrew M. 1999. A Fire You Can't Put Out: The Civil Rights Life of Birmingham's Reverend Fred Shuttlesworth. Tuscaloosa, AL: University of Alabama Press.

Marger, Martin N. 1984. "Social Movement 
Organizations and Response to Environmental Change: The NAACP, 1960-1973." Social Problems 32:16-30.

Matthews, Donald R. and James W. Prothro. 1963. "Political Factors and Negro Voter Registration in the South." American Political Science Review 57:355-67.

-1966. Negroes and the New Southern Politics. New York: Harcourt, Brace and World.

1975. Negro Political Participation Study, 1961-1962. [computer file] Interuniversity Consortium for Political and Social Research.

McAdam, Doug. 1982. Political Process and the Development of Black Insurgency, 1930-1970. Chicago, IL: University of Chicago Press.

- 1983. "Tactical Innovation and the Pace of Insurgency." American Sociological Review 48:735-54.

—. 1995. "Conceptual Origins, Current Problems, Future Directions." Pp. 23-40 in Comparative Perspectives on Social Movements, edited by D. McAdam, J. D. McCarthy, and M. N. Zald. New York: Cambridge University Press.

McAdam, Doug and Dieter Rucht. 1993. "The CrossNational Diffusion of Movement Ideas." Annals of the American Academy of Political and Social Sciences 528:56-74.

McAdam, Doug and William H. Sewell, Jr. 2001 "It's About Time: Temporality in the Study of Social Movements and Revolutions." Pp. 89-125 in Silence and Voice in the Study of Contentious Politics, edited by R. R. Aminzade, J. A. Goldstone, D. McAdam, E. J. Perry, W. H. Sewell, Jr., S. Tarrow, and C. Tilly. Cambridge, England: Cambridge University Press.

McAdam, Doug, Tarrow Sidney, and Tilly Charles. 2001. The Dynamics of Contention. Cambridge, England: Cambridge University Press.

Meier, August and Elliott Rudwick. 1973. CORE: A Study in the Civil Rights Movement. New York: Oxford University Press.

1976. "The Origins of Nonviolent Direct Action in Afro-American Protest: A Note on Historical Discontinuities.” Pp. 307-404 in Along the Color Line, edited by A. Meier and E. Rudwick. Urbana, IL: University of Illinois Press.

Meyer, David and Debra Minkoff. 2004 "Conceptualizing Political Opportunity." Social Forces 82:1457-92.

Mitchell, Glenford E. 1962. "College Students Take Over." Pp. 73-95 in The Angry Black South, edited by G. E. Mitchell and W. H. Peace. New York: Corinth.

Morris, Aldon D. 1981. "Black Southern Student Sit-in Movement: An Analysis of Internal Organization." American Sociological Review 36:744-67.

- 1984. The Origins of the Civil Rights Movement. New York: Free Press.

Morris, Aldon D. and Naomi Braine. 2001. "Social
Movements and Oppositional Consciousness." Pp. 20-37 in Oppositional Consciousness: The Subjective Roots of Social Protest, edited by Jane Mansbridge and Aldon Morris. Chicago, IL, and London, England: University of Chicago Press.

Myers, Daniel J. 1997. "Racial Rioting in the 1960s: An Event-History Analysis of Local Conditions." American Sociological Review 62:94-112. 2000. "The Diffusion of Collective Violence: Infectiousness, Susceptibility, and Mass Media Networks." American Journal of Sociology 106:173-208.

—. 2001. "Modeling Social Diffusion Processes Using Event-History Analysis," Discussion paper, Institute of Social and Economic Research and Policy, Columbia University, New York.

Myers, Daniel J. and Beth Schaefer Caniglia. 2004 "All the Rioting That's Fit to Print: Selection Effects in National Newspaper Coverage of Civil Disorders, 1968-1969." American Sociological Review 59:519-43.

NAACP. [1960]. Special Report on the Sitdowns: NAACP Staff Activity in the Sitdowns, Branch Department. NAACP Papers, Part 19, Section D, Reel 19.

Oberschall, Anthony. 1973. Social Conflict and Social Movements. Englewood Cliffs, NJ: Prentice-Hall. . 1989. "The 1960s Sit-ins: Protest Diffusion and Movement Take-Off." Research in Social Movements, Conflict and Change 11:31-53.

Oliver, Pamela E. and Daniel Myers. 2003. "The Coevolution of Social Movements." Mobilization 8:1-25.

Olzak, Susan, Maya Beasley, and Johan Olivier. 2003. "The Impact of State Reforms on Protest Against Apartheid in South Africa." Mobilization 8:27-50.

Oppenheimer, Martin. 1963. "The Genesis of the Southern Negro Student Movement (Sit-in Movement)." Ph.D. dissertation, Department of Sociology, University of Pennsylvania, Philadelphia, PA.

Orum, Anthony M. 1972. Black Students in Protest: $A$ Study of the Origins of the Black Student Movement. Washington, DC: American Sociological Association.

Patrick, Clarence H. 1960. Lunch-Counter Desegregation in Winston-Salem, North Carolina. Department of Sociology, Wake Forest College.

Peace, William H., III. 1962. “The South Reacts.” Pp. 96-127 in The Angry Black South, edited by G. E. Mitchell and W. H. Peace. New York: Corinth.

Peck, James. 1962. Freedom Ride. New York: Grove. Piven, Frances Fox and Richard Cloward. 1977. Poor People's Movements. New York: Pantheon.

Polletta, Francesca. 1998. “ “It Was Like a Fever. .' Narrative and Identity in Social Protest." Social Problems 45:137-59. 
Pollitt, Daniel. 1960. "Dime Store Demonstrations." Duke Law Journal 9:315-65.

Powledge, Fred. 1991. Free at Last? Boston, MA: Little, Brown.

Rabby, Glenda Alice. 1999. The Pain and the Promise: The Struggle for Civil Rights in Tallahassee, Florida. Athens, GA: University of Georgia Press.

Raines, Howell. 1977. My Soul Is Rested. New York: Penguin.

Rogers, Kim Lacy. 1993. Righteous Lives: Narratives of the New Orleans Civil Rights Movement. New York: New York University Press.

Roscigno, Vincent J. and William F. Danaher. 2000. "Media and Mobilization." American Sociological Review 66:21-48.

Salamon, Lester, and Stephen Van Evera. 1973. "Fear, Apathy and Discrimination: A Test of Three Explanations of Political Participation." American Political Science Review 67:1288-306.

Searles, Ruth and J. Allen Williams. 1962. "Negro College Students' Participation in Sit-ins." Social Forces 40:215-20.

Sindler, Allan P. 1965. Negro Politics and Local Politics in Durham, NC. New York: McGraw-Hill.

Sitkoff, Harvard. 1993. The Struggle for Racial Equality. New York: Hill and Wang.

Smith, Charles U. 1961. "The Sit-Ins and the New Negro Student." Journal of Intergroup Relations 2:223-29.

Smith, Jackie, John D. McCarthy, Clark McPhail, and Boguslaw Augustyn. 2001. "From Protest to Agenda Building: Description Bias in Media Coverage of Protest Events in Washington, DC." Social Forces 79:1397-423.

Soule, Sarah A. 1997. "The Student Divestment Movement in the United States and Tactical Diffusion." Social Forces 75:855-83.

-1 1999. "The Diffusion of an Unsuccessful Innovation: The Case of the Shantytown Protest Tactic." The Annals of the American Academy of Political and Social Science 566:120-31.

Southern Regional Council. 1960. "Special Report: The Student Protest Movement, Winter 1960." SRC-13.

Standard Rate and Data Service. 1960. SRDS Newspaper Circulation Analysis, 1960 ed. Skokie, IL: Standard Rate and Data Service.

Strang, David and Nancy Brandon Tuma. 1993. "Spatial and Temporal Heterogeneity in Diffusion." American Journal of Sociology 99:614-39.

Sumner, David E. 1989. "The Local Press and the Nashville Student Movement, 1960.” Ph.D. dissertation, College of Communications, University of Tennessee, Knoxville, TN.

Tarrow, Sidney. 1998. Power in Movement. 2d ed. Cambridge, England: Cambridge University Press.

Tarrow, Sidney and Doug McAdam. 2005. "Scale Shift in Transnational Contention." Pp. 121-150 in Transnational Processes and Social Movements, edited by D. della Porta and S. Tarrow. Boulder, CO: Rowman and Littlefield.

Tilly, Charles. 1977. "Getting It Together in Burgundy, 1675-1975." Theory and Society 4:479-504.

1995. Popular Contention in Great Britain,

1758-1834. Cambridge, MA, and London, England: Harvard University Press.

Tolnay, Stewart E., Glenn Deane, and E. M. Beck. 1996. "Vicarious Violence: Spatial Effects on Southern Lynchings, 1890-1919." American Journal of Sociology 102:788-815.

Tomz, Michael, Gary King, and Langche Zeng. 1999. Relogit: Rare Events Logistic Regression, Version 1.1. Cambridge, MA: Harvard University.

Traugott, Mark. 1993. "Barricades as Repertoire: Continuities and Discontinuities in the History of French Contention." Social Science History 17:309-23.

Tyson, Timothy. 2004. Blood Done Sign My Name. New York: Crown.

U.S. Bureau of the Census. 1963. Census of Population, 1960, Vol. 1: Characteristics of the Population. Washington, DC: Government Printing Office.

U.S. Commission on Civil Rights. 1959. Report of the United States Commission of Civil Rights, 1959. Washington, DC: Government Printing Office.

Van den Bulte, Christophe and Gary L. Lilien. 2001. "Medical Innovation Revisited: Social Contagion versus Marketing Effort." American Journal of Sociology 106:1409-35.

Van Dyke, Nella. 1998. "Hotbeds of Activism." Social Problems 45:205-19.

Viorst, Milton. 1979. Fire in the Streets: America in the 1960s. New York: Touchstone.

Walker, Jack L. 1964. Sit-Ins in Atlanta. New York: McGraw-Hill.

Walzer, Michael. 1960. "A Cup of Coffee and a Seat." Dissent 7:111-20.

Ward, Brian. 2004. Radio and the Struggle for Civil Rights in the South. Gainesville, FL: University of Florida Press.

Warren, Robert Penn. 1965. Who Speaks for the Negro? New York: Vintage.

Wehr, Paul. 1960. "The Sit-Down Protests.” M.A. thesis, Department of Sociology, University of North Carolina, Chapel Hill, NC.

Wolff, Miles. 1970. Lunch at the Five and Ten. New York: Stein and Day.

Wynn, Linda T. 1991. "The Dawning of a New Day: The Nashville Sit-Ins, February 13-May 10, 1960." Tennessee Historical Quarterly 50:42-54

Zhao, Dingxin. 1998. "Ecologies of Social Movements." American Journal of Sociology 103:1493-529.

Zinn, Howard. 1964. SNCC: The New Abolitionists. Boston, MA: Beacon. 